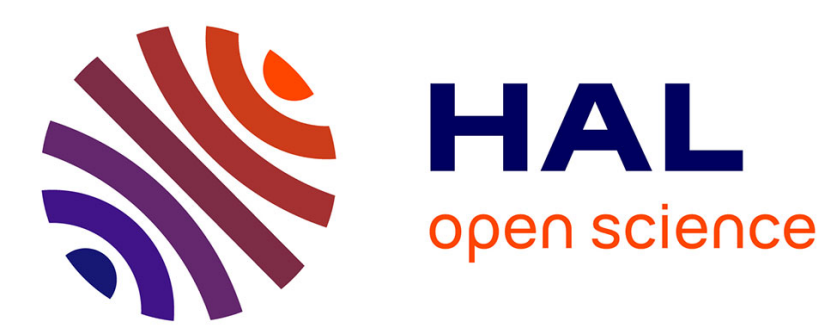

\title{
Economics of biosecurity across levels of decision-making: a review
}

\author{
Heikkilä
}

\section{To cite this version:}

Heikkilä. Economics of biosecurity across levels of decision-making: a review. Agronomy for Sustainable Development, 2011, 31 (1), pp.119-138. 10.1051/agro/2010003 . hal-00930468

\section{HAL Id: hal-00930468 https://hal.science/hal-00930468}

Submitted on 1 Jan 2011

HAL is a multi-disciplinary open access archive for the deposit and dissemination of scientific research documents, whether they are published or not. The documents may come from teaching and research institutions in France or abroad, or from public or private research centers.
L'archive ouverte pluridisciplinaire HAL, est destinée au dépôt et à la diffusion de documents scientifiques de niveau recherche, publiés ou non, émanant des établissements d'enseignement et de recherche français ou étrangers, des laboratoires publics ou privés. 


\title{
Review article
}

\section{Economics of biosecurity across levels of decision-making: a review}

\author{
Jaakko HEIKKILÄ* \\ MTT Economic Research, Luutnantintie 13, 00410 Helsinki, Finland
}

(Accepted 14 December 2009)

\begin{abstract}
Biosecurity is a concept that has important economic, social, ecological and health-related dimensions. By biosecurity we mean protection of production, ecosystems, health and the social infrastructure from external threats caused by pests, pathogens and diseases of various forms and origins. The fact that more goods, transport platforms and people are moving around the globe at increasing speeds provides unforeseen possibilities for rapid spread of different types of organisms. This is exacerbated by changes in the production structures and climate. As a result, both the benefits and the risks of changes in the food system cross borders more often, leading to an increased demand for biosecurity policies. Economics can be related to biosecurity in at least three fundamental ways. First, many of the ultimate or proximate causes of bioinvasions create economic welfare. Second, bioinvasions result in various types of impacts, many of which are economic by nature - or at least may be measured in economic terms. Third, the negative impacts of invasions or their probability of occurrence can often be either avoided or reduced. These biosecurity policies themselves have economic implications, which often may be quite different from those caused by the biological hazard itself. A few reviews of separate components of economics of biosecurity exist, but there have been no attempts to review the big picture. Instead, the previous reviews have concentrated on different components of biosecurity such as invasive species or animal diseases. Our aim is to look at the issue in broad terms, draw some commonalities from the research conducted, and identify areas in which economic analyses have primarily been conducted and in which areas there remains work to do. The review includes about 230 studies from all areas of biosecurity up to the year 2008. The review finds that study of economics of biosecurity is growing steadily, but is still relatively concentrated on narrow questions, few countries, few species/diseases and few journals.
\end{abstract}

biosecurity / economics / invasive species / pests / diseases / review

\section{Contents}

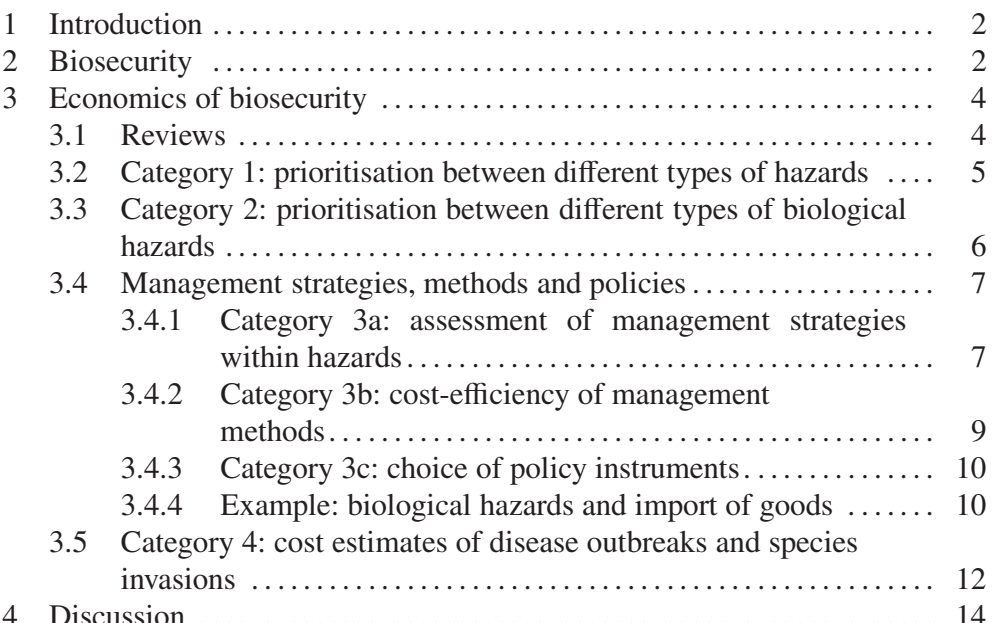

\footnotetext{
*Corresponding author: jaakko.heikkila@mtt.fi
} 


\section{INTRODUCTION}

Biosecurity is a concept that has important economic, social, ecological and health-related dimensions. By biosecurity we mean protection of production, ecosystems, health and the social infrastructure from external threats caused by pests, pathogens and diseases of various forms and origins. In this paper, we call these external biological threats collectively 'biological hazards'. An entry of a biological hazard is referred to as an 'invasion'.

The ultimate global forces that accelerate invasions by biological hazards include changes in production structure and land use, climatic change and globalisation (see, e.g., Daily and Ehrlich, 1996). In this context globalisation refers to the increasing integration of markets for goods, services and capital throughout the world. This leads to an increased volume of transactions and reduced trade barriers and transaction costs, all driven by the gains of trade. The fact that more goods, transport platforms and people are moving around the globe at increasing speeds also provides unforeseen possibilities for rapid spread of different types of organisms. This is exacerbated by changes in the production structures and climate. As a result, both the benefits and the risks of changes in the food system cross borders more often, leading to an increased demand for biosecurity policies.

Some of the organisms that are moved provide positive economic impacts on the receiving economic system, and some provide negative economic impacts. Some organisms produce both (often intended) positive impacts as well as (often unintended) negative impacts, with the net impact being sometimes difficult to determine. Nonetheless, the fact that species transfer is an issue that cannot be defined as dominantly beneficial or dominantly harmful makes biosecurity policy challenging to design and implement.

Economics is related to biosecurity in at least three fundamental ways. First, many of the ultimate or proximate causes of bioinvasions create economic welfare. Be it related to transport, tourism and trade, or to urbanisation, migration and agricultural intensification, many outcomes of economic decisionmaking provide incentives or means for species and diseases to be moved around the world. Second, bioinvasions result in various types of impacts, many of which are economic by nature - or at least may be measured in economic terms. These include damage to production processes, health and the environment (see, e.g., FAO, 2001). Third, the negative impacts of invasions or their probability of occurrence can often be either avoided or reduced. These biosecurity policies themselves have economic implications, which often may be quite different from those caused by the biological hazard itself.

A few reviews of separate components of economics of biosecurity exist, but there have been no attempts to review the big picture. Instead, the previous reviews have concentrated on different components of biosecurity such as invasive species (Born et al., 2005; Gren, 2008; Heikkilä, 2006; Olsson, 2006) or animal diseases (Elbakidze, 2003). Our aim is to look at the issue in broad terms, draw some commonalities from the research conducted, and identify areas in which economic anal- yses have primarily been conducted and in which areas there remains work to do.

The review includes 231 studies from all areas of biosecurity up to the year 2008. The review finds that study of economics of biosecurity is growing steadily, but is still relatively concentrated on narrow questions, few countries, few species/diseases and few journals. The following priority themes (in no particular order) are suggested for further study: (1) sophisticated economic policy instruments to mitigate biological hazards; (2) rigorous economic prioritisation frameworks; (3) clearer understanding of the distribution of biosecurity impacts and the associated incentives; (4) closer links with the costs and methods of prevention to the economic risk; and (5) the role of human behaviour in biosecurity and how that behaviour can best be directed.

The rest of the paper is organised as follows. In Section 2 we briefly define biosecurity and economics of biosecurity in order to clarify which questions and topics are included in the review. In Section 3 we first discuss existing reviews, and then review the existing studies based on the framing of the research question. In Section 4 we draw some conclusions as well as giving recommendations for further study.

\section{BIOSECURITY}

Biosecurity provides an appropriate framework for managing the risks presented by biological hazards. It can be defined as the exclusion, eradication and effective management of risks posed by pests and diseases to the economy, environment and human health (Biosecurity Council, 2003). The main targets for biosecurity policies include environmental, commercial, cultural, human health-related, and social objectives. The FAO (2003) sees biosecurity as the "process and objective of managing biological risks associated with food and agriculture in a holistic manner". Policy is here defined as any instrument or institution that is working to reduce the risks (i.e. either probability or impact) of biological hazards. Although parts of biosecurity, this review excludes studies on genetically modified organisms (GMOs) and diseases that are confined solely to humans.

The four main elements that biosecurity policies protect include human health, animal health, plant health and environmental health, including the health of the built environment. Each category will be shortly discussed below. However, it is worth noting that many biological hazards are not limited to a certain category. Instead, a particular species or disease may cause detrimental impacts in several ways and in several sectors. For instance, avian influenza is of concern for human, animal and environmental health.

The human health aspect of biosecurity includes zoonotic diseases (diseases communicable between animals and humans) and biological food safety. Hazards may be divided into bacteria (e.g. salmonella), viruses (e.g. avian influenza and HIV/AIDS), protozoa (e.g. the malaria parasite Plasmodium spp.), fungi and worms (e.g. trichinosis), and prions (e.g. bovine spongiform encephalopathy, BSE) (Delfino and Simmons, 2000). The importance of biological hazards that 
threaten human health is vast (see e.g. Wolfe et al., 2007). For instance, smallpox was perhaps the largest single cause of death in the 20th century, and the Spanish flu of 1918 (H1N1type avian influenza) killed approximately 40-50 million people and attacked the young disproportionately (IMF, 2006). Today, on a global scale communicable diseases are estimated to cause about a quarter of all mortality and morbidity, and even in industrial countries one-third of the population acquire annually a disease caused by a foodborne microbe (WHO, 2007).

The human health component includes not only physi$\mathrm{cal} /$ biological health, but also social health. This refers to human wellbeing separate from mere infection by a disease. For instance, many animal diseases and government policies related to animal diseases are likely to affect social health. This may be due to, for example, movement restrictions that result in social isolation, or disposal of infected animal carcasses (e.g. Rossides, 2002; Mort et al., 2005; Dixon, 2007). Welfare reduction may also result from loss of cultural heritage and spiritual or religious values when, for instance, a traditional ecosystem is transformed into an ecosystem dominated by exotic species.

Animal health is another component of biosecurity, including animal diseases as well as animal predators, parasites and parasitoids. The importance of animal health is likewise vast. For instance, in North America and Europe calories of the human diet are mainly obtained from animal products (Carvalho, 2006). Examples of diseases threatening animal health include classical swine fever, rinderpest, Newcastle disease and Aujeszky's disease. In addition, zoonotic diseases are an animal health issue as well as a human health issue. For instance, Ebola haemorrhagic fever has caused the death of thousands of gorillas in Gabon and the Republic of Congo (Bermejo et al., 2006).

The plant health aspect of biosecurity includes plant diseases and pests. The injurious effect may be direct, as in the case of pests that directly affect the plant, such as pathogens, parasites and herbivores, but it may also be indirect, as in the case of weeds that compete for biotic or abiotic resources, or any other organism impacting on the plant indirectly (Schrader and Unger, 2003). Plant production provides the basis of the human food chain, and it is therefore a crucial target of biosecurity. In addition, forest products are a source of significant revenue for many countries, both in the developed world (timber, recreation, biodiversity, berries) as well as in the developing world (forage, construction, fuelwood, biodiversity, medicine). About $75 \%$ of calories in a balanced human diet are from plant products (Carvalho, 2006). For instance, the famine in Ireland in the 1840s was caused by Phytophtora infestans a fungus that arrived from North America and destroyed the Irish potato harvest (Schrader and Unger, 2003).

Health of the environment and built environment is the fourth component of biosecurity. Invasive alien species may be harmful to environmental health through various kinds of biotic or abiotic interactions (including, for instance, predation, competition, interbreeding and spread of diseases). For example, the Arundo donax giant reed, which is currently under consideration for bioenergy production in Europe, has been found to have detrimental ecosystem impacts in California riversides (Hundley, 2007). We also include the built environment within environmental health. Examples are provided by, for instance, damage to roads, runways and parks caused by rabbits (Gebhardt, 1996) or damage to power-plant intake pipes by the zebra mussel (Pimentel et al., 1999, 2005; Connelly et al., 2007).

The aspects of biosecurity discussed above, as well as the concepts of biosecurity, food safety and dietary safety are clarified in Figure 1. The figure illustrates that there are components of food safety not included within the definition of biosecurity, as well as several other factors affecting the health of humans. For instance, human health is partly affected by biosecurity (e.g. foodborne microbes and zoonotic diseases), partly by non-biological aspects of food safety (e.g. acute chemical substances), partly by dietary safety (e.g. accumulating chemical substances), partly by the way of life not related to the environment or biological hazards (e.g. sports, stress), and partly by the environmental factors surrounding us (e.g. noise, temperature). While it is true that, for instance, exotic plant pests can drive changes in risks of natural forces (e.g. fire regime), such feedbacks are not presented in the figure.

Biosecurity is primarily about managing risk and uncertainty. Risk in economic terms is a continuum of possible events and future states of the world. Put simply, the economic risk is the probability of an event (or future path) multiplied by the economic costs and benefits that ensue if that path materialises. The risk is thus affected by the likelihood of an event as well as the net cost (costs less benefits) of that event. The probability and the impacts are usually not known with certainty.

Uncertainty may be divided into uncertainty regarding biological and natural processes and uncertainty regarding human factors (Heal and Kriström, 2002). Regarding natural processes, there may be uncertainty and natural stochastic variation in the invasion process and subsequent spread processes. Uncertainty regarding the human factors arises from human preferences and decision-making as well as from the functioning of the society and its institutions. These include issues such as how biosecurity hazards and policies affect human systems, and how some unknown economic values (such as the value of life or the discount rate) affect the evaluation. Thus, even if we knew the science behind certain natural science phenomena with certainty, the impacts of such phenomena on the various components of human societies may remain uncertain. For instance, it is unknown how the continued presence of the biosecurity hazards would affect the production patterns or land use in the longer run. In addition, there may be uncertainty related to which policies are needed to address the problems, how those policies impact on the issue in question and what the costs of undertaking these policies are (Heal and Kriström, 2002).

An important implication here is that the risk is an endogenous process that is affected not only by the biological processes, but also by the human activities that create the risk as well as human reactions to the risk. For instance, it has been shown that socio-economic variables are significant in explaining the invasion process in the context of plants 


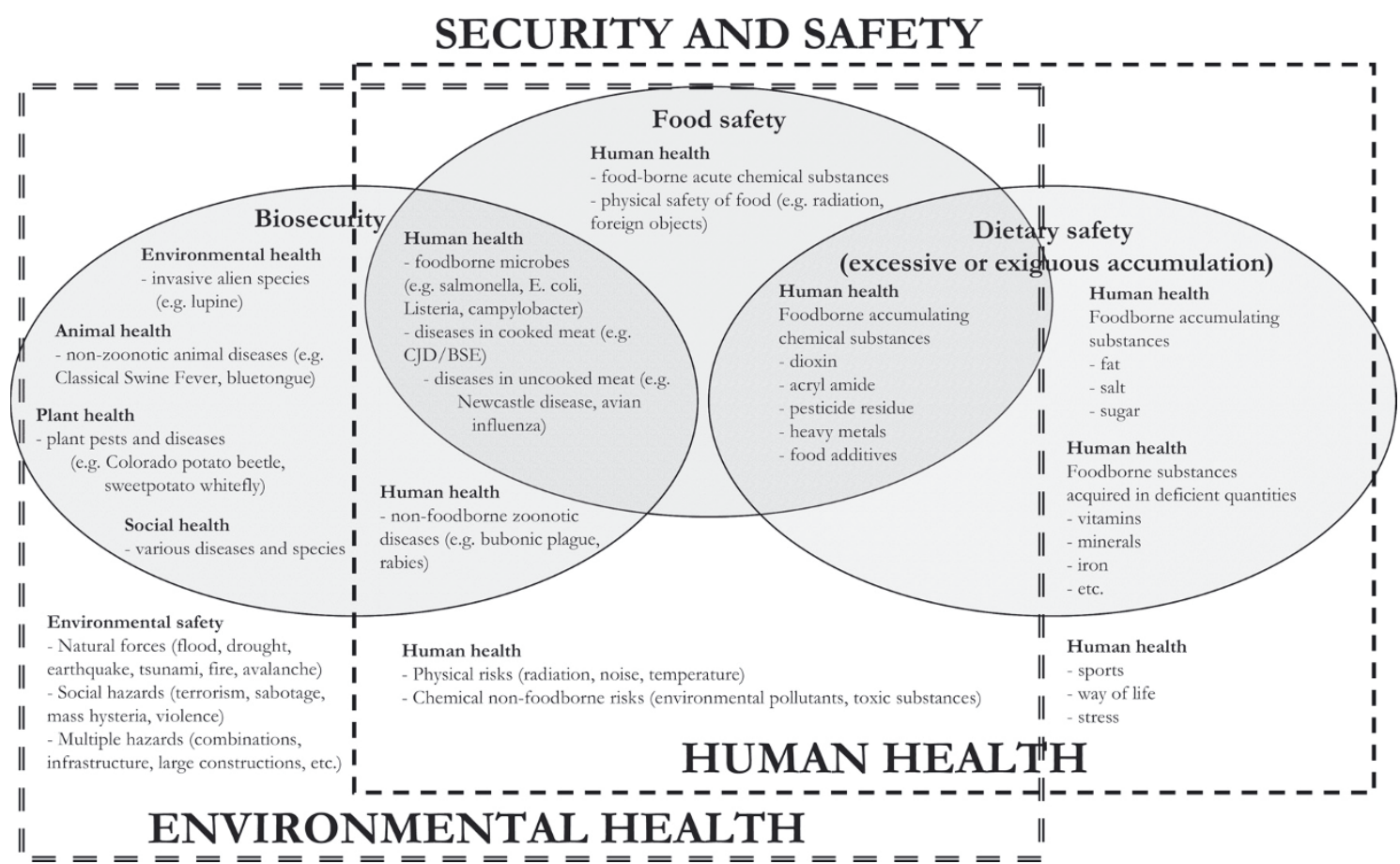

Figure 1. Biosecurity, food safety and dietary safety (after Heikkilä, unpublished).

(Dehnen-Schmutz et al., 2007; Dalmazzone, 2000), marine species (Weigle et al., 2005), insects (Work et al., 2005) and infected meat imports (Wooldridge et al., 2006). So risk is as much an economic question as a biological one (Mumford et al., 2000). It is a matter of allocating resources so that the negative effects of risk are reduced enough compared with efforts required to reduce the risk.

Despite risk and uncertainty, we would like to maximise social net benefits. There are several actions that we may take to deal with risk. First, risk may be avoided. This can be achieved by, for instance, not using (or trading) a potentially risky good and thus foregoing the utility from the good. Second, the realisation of the risk may be avoided. This requires increased surveillance at all levels, extra care in the use of the good, and quality management in the entire production and consumption chain. Third, we may accept the presence of the risk. This means getting prepared to face the consequences and manage them in the case that the risk materialises. Fourth, risk may be transferred by, for instance, hedging, insuring or diversifying.

Biosecurity thus involves protection of various environmental and anthropogenic elements in an uncertain world against the threat presented by biological hazards. The primary question in most economic studies (albeit not explicitly stated in most of them) is: what should we do about this risk?

\section{ECONOMICS OF BIOSECURITY}

\subsection{Reviews}

There have been a few reviews of separate sections within the economics of biosecurity. Olson (2006) reviews economics of terrestrial invasive species. He suggests that there has been rapid development in the field, but uncertainty, spatial modelling, prevention, trade, and conflict between private and public incentives are areas where more sophisticated analyses are needed. Gren (2008) reviews invasive species studies in relation to two questions: (1) how to set targets for species damage mitigation; and (2) which policy instruments are best in achieving the targets. Her results indicate that strategies for prevention, control and damage reduction are complementary, and ignoring any one of them may impose social costs. She also argues that there is a lack of empirical applications and of studies evaluating current regulations.

There are also two reviews on cost-benefit types of studies. Born et al. (2005) review the economic cost-benefit evaluations of invasive species. Their main conclusions are that: (1) studies mostly have methodological shortcomings; (2) assessments are mostly ex-post rather than ex-ante; (3) prevention is hardly reflected in the analyses; and (4) uncertainty is insufficiently addressed. They conclude that most studies "focus on ex-post evaluation, on control measures, on few countries, on agriculture, and on use values" (Born et al., 2005).

Similar conclusions are reached in a review by Heikkilä (2006), who makes three basic observations on studies on invasive species in an agricultural context. First, the policy alternatives evaluated are often simply undertaking some policy versus not undertaking it. The most common analysis seems to be between a current protective policy versus abandoning it. Wider policy options are generally either not available or not analysed. Second, it is often only the direct, easily monetised costs that are included in the quantitative analysis. Costs that are more difficult to analyse - such as trade or employment 
effects - are often ignored altogether, even though in the cases where they are included they turn out to be very important. Third, sensitivity analyses and treatment of uncertainty are in many cases inadequate, if conducted at all. Heikkilä (2006) also notes that in many cases invasive species cost-benefit studies are not written by economists. The same can be argued to apply to research on animal diseases. In fact, Adamson and Cook (2007) go so far as to argue that standardised approaches to economic evaluations have not been developed and economic reviews are generally undertaken by consultants. As a result, the economic foundation of the studies is not as strong as it could be.

Elbakidze (2003) reviews the economics of agricultural biosecurity in relation to bioterrorism and argues that especially in relation to foot and mouth disease surveillance and detection (early actions) are overlooked in studies compared to vaccination and slaughter (reactive actions) - an idea shared by Born et al. (2005) in relation to invasive species. McInerney et al. (1992) concluded that economic studies on livestock disease concentrate on cost-benefit analyses of control programmes or gross estimates of costs of particular diseases, neither of which offers an adequate basis for economic decisions. There are also reviews on economics of specific biological hazards; for instance, on bovine viral diarrhoea virus (Houe, 2003) and parasitic diseases of production animals (Perry and Randolph, 1999).

Economics is about the scarcity of resources, and how to allocate the available resources in the best possible way to maximise the objectives set by the decision-maker. It has been noted that the role of economics can be to evaluate a chosen policy, to identify the most cost-effective measures to attain a specified goal, or to prioritise between different goals and measures (Goldbach and Alban, 2006). Embedded in this notion is the fact that there are various hierarchical levels at which economic decisions need to be made. Ideally, research that attempts to answer such questions would involve simultaneous considerations of the management strategy, objectives within the strategy and the tools to achieve those objectives in the best possible manner. The objective, after all, should be to maximise (social) net benefits subject to given constraints.

However, individual papers rarely discuss the whole management issue. Instead, the research question is often limited to, for instance, evaluation of specific management alternatives. Therefore, in this review the existing studies are organised categorically, based on the aims of the research setting in which they study biosecurity economics. The first category is priority-setting between different kinds of hazards confronting human society including, for instance, biological, chemical, social and military hazards. The second category is prioritysetting between different kinds of biological hazards; for instance, between invasive species and animal diseases, which are often administered in separate ministries. The third category is divided into three subcategories. The first subcategory is evaluation of management strategies to deal with a biological hazard; for instance, prevention versus adaptation. The second subcategory is the cost-efficiency of different management methods; for instance, questions such as the optimal tax level or the optimal pre-emptive slaughter radius around infected

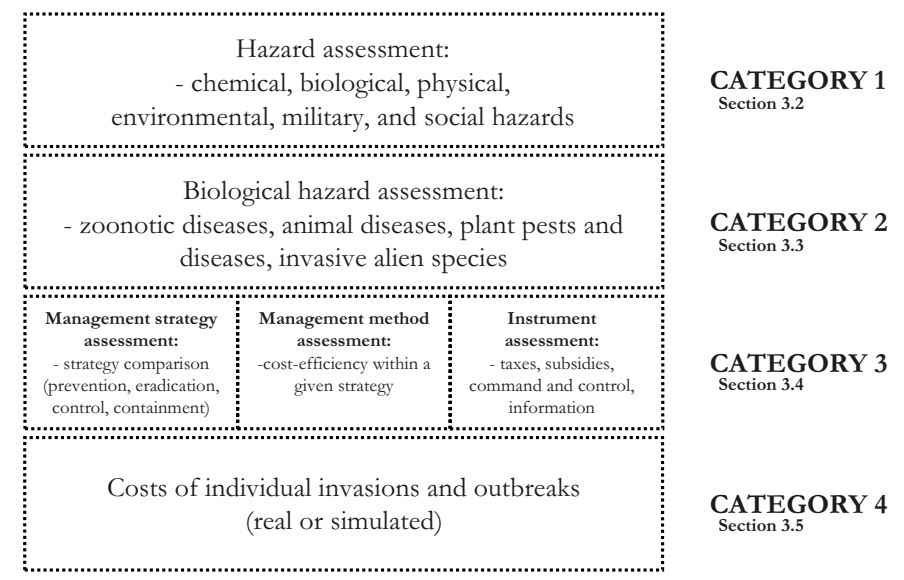

Figure 2. Categorisation of economic biosecurity studies.

premises. The third subcategory deals with the evaluation of the available policy instruments aiming to achieve the desired outcome of the chosen management strategy - for instance, whether we should use economic instruments or command and control instruments. Finally, the fourth category deals with the assessment of impacts (usually costs) of specific invasions or outbreaks, and is often done given the prevailing strategies, policy instruments and management methods. Such assessments usually do not include any comparisons but rather an outright monetary evaluation of the incurred or simulated costs.

These categories are presented in Figure 2 and reviewed in more detail below. Additionally, two examples are discussed. The first example deals with a very common setting in management strategy assessment of category 3 , namely the choice between prevention versus adaptation strategy. The second example deals with import risk, and discusses the types of studies dealing with this risk. Whilst ideally the question would be tackled as an entity, the examples demonstrate how individual studies often address more specific questions.

\subsection{Category 1: prioritisation between different types of hazards}

Renn (2006) divides hazardous agents into biological agents, physical agents (radiation, temperature, noise), chemical agents (pollutants, carcinogens), natural forces (drought, flood, tsunami, hurricane, fire, avalanche, earthquake), socially communicative hazards (terrorism, sabotage, mass hysteria, violence), and complex hazards (combinations of the above). How the society's resources are divided among these hazards is to a large extent a political question, and has not to our knowledge been studied academically. Having said that, we do not see any intrinsic reasons why such an exercise could not be undertaken. Naturally, comparison and estimation of risks and costs associated with such a wide variety of hazards is complex, and no easy solutions for comparison are available. The risks and impacts of such hazards may show such variety that they are, in addition to being difficult to value, very difficult 
to compare with one another. For instance, comparing the impacts of a materialising military hazard with the loss of welfare from burning animal carcasses may prove to be a daunting exercise.

Yet, resource allocations are constantly made at the level of the government as decisions regarding allocation of resources between, say, ministries of the environment (invasive species) and agriculture (health of production animals and plants) are made. Studies on individual hazards can achieve deeper understanding of the specific circumstances, but it would be worthwhile having analyses of the larger issues and trade-offs present at higher levels to assist such resource allocation issues. For instance, how resources should be allocated regarding chemical versus biological hazards in food products would already be a prioritisation question in this category. This has, indeed, been studied to some extent (Valeeva et al., 2007, 2006).

\subsection{Category 2: prioritisation between different types of biological hazards}

In this category the focus is purely on biological hazards. These can be divided into hazard categories as discussed in Section 2 (human, animal, plant and environmental health). Economic prioritisation can take place at two levels: (1) between different categories and (2) within the categories. As far as we are aware, prioritisation between the categories - for instance, comparing the economic risk presented by animal diseases to risks posed by plant diseases - has not taken place. However, for comparison of benefits from protection against different kinds of biological hazards, see Waage et al. (2005).

Instead, some comparisons within the hazard categories have taken place. In fact, such actions are also already politically sought for within animal diseases: the European Union is seeking to harmonise animal health policy and is looking for a single legal framework to bring together trade, imports, animal disease control, nutrition and welfare. It aims to introduce a scheme for classifying and prioritising animal diseases and disease prevention according to their economic or human health impact (European Commission, 2006). Somewhat similar plans are underway regarding plant health and invasive alien species and, for instance, risk-based surveillance overall is becoming increasingly popular (McKenzie et al., 2007), but these trends have not yet materialised as clearly as in the case of animal health.

The problem in lack of such assessments is that the resource allocation may be inefficient. As some kind of allocation is in any case made, if it is not based on (economic) assessment of the risks, it is based on something else. For instance, Virtue (2007) points out that in Australia too many species have been declared weeds in order to effectively contain or eradicate them all. Australian regions are argued to focus on widespread species for various reasons, including a long history of control, high visibility, political pressure, perceived impacts, shared burden of control, familiarity, and agricultural bias. Economic prioritisation has rarely played a part in such choices (Virtue, 2007). Similarly, risk is not the primary determining factor in control of many animal diseases (Rosengren and Heikkilä, 2009).

A few rigorous economic studies exist that prioritise hazards within certain categories. In addition, there are several studies that include some sort of risk ranking of biological hazards, including their economic impacts, but where the methodologies are less rigorous. In the first of the two more rigorous studies that we are aware of, Moffitt and Osteen (2006) study prioritisation of invasive species threats under uncertainty. They examine different decision rules and develop a priority list of potential agricultural crop pests in the United States to demonstrate the criteria. The other example is Cook (2005), who studies the critical level of investment in pest exclusion in Western Australia. He provides a framework that allows prioritisation of pests based on damage and production cost increases, and also identifies a critical level of expected damage associated with the pest that can be used as a ceiling for incursion expenditure. If this level is exceeded, other control options such as containment or adaptation should be considered. Using a static partial equilibrium model, the study considers a range of host plants.

Various hazard ranking studies are usually somewhat less rigorous from an economic perspective. This type of ranking usually follows the basic structure of Covello-Merkhofer risk assessment, including release, exposure and consequence assessments, which are combined to form a risk estimate (Peeler et al., 2007). The approach has been applied to, for instance, weeds in the US (Parker et al., 2007) and in Europe (Weber and Gut, 2004), to ants (Harris, 2005) and wildlife pathogens (McKenzie et al., 2007) in New Zealand, and to plant pests in Western Australia (Cook and Proctor, 2007). In these assessments the basic themes relate to what components are included in the risk ranking, how they are scored and aggregated, and how the opinions are formed.

Hazard ranking is based on separate components that together form the ranking order. The components typically include the probability of entry (or invasion or introduction or outbreak), the probability of spread (or invasiveness), and the likely consequences, which may or may not be measured in monetary terms. In most cases the ranking is on an arbitrary scale (e.g. 1 to 5), and the overall rank is obtained by summing up the different component values (e.g. Harris, 2005). Also, multiplicatory scoring is used, in which case the rank approaches zero if any of the individual components does so. This approach may be augmented by a measure for the feasibility of control. For instance, Virtue (2007) augments the risk measure by a containment feasibility measure, which is the product of control costs, current distribution and persistence. Rank is then obtained by dividing the risk measure by the control feasibility measure. The priority assessment is usually done using either expert opinion on its own (Weber and Gut, 2004; Cook and Proctor, 2007) or combined with a literature review (McKenzie et al., 2007). As pointed out by Cook and Proctor (2007), different juries are likely to produce different results.

Such prioritisation assessments are not without both theoretical and methodological problems, and the resulting rank 
order does not act as a decision-rule in itself. The rank order often illustrates the risk presented by the organism, not the benefit that would be achieved when investing a unit of control in it. Even so, a formal framework that approaches the problem in a standardised manner and helps in thinking through the issues involved is better than basing the decisions on, for instance, history, personal opinion or political pressure. A more detailed discussion on risk ranking is presented in Heikkilä (unpublished).

\subsection{Management strategies, methods and policies}

Study of biosecurity economics in category 3 is ideally a continuum and a holistic exercise in which the management strategy, the management methods to undertake that strategy and the policy instruments to obtain the desired outcome are evaluated simultaneously. However, this ideal is seldom achieved, at least in individual research papers. Instead, the choice between strategies, management methods or policy instruments is often made given the other factors. Hence in this review the studies are divided according to the objectives of the studies.

\subsubsection{Category 3a: assessment of management strategies within hazards}

Biological hazards may be managed through various strategies, including prevention, eradication, containment and control (CBD, 1992; Council of Europe, 2003; Shine et al., 2000). If prevention fails, the most extensive measure is to eradicate the entire invasive population or the disease. Within the realm of certain animal diseases and in the case of some plant pests or diseases, eradication may be an automatic action if the hazard is encountered. In the case of invasive species threatening the environment, such decisions are likely to be made much more on an ad hoc basis. For examples of eradication successes and failures, see Genovesi (2005) and Simberloff (2003). If eradication is found not to be feasible or economical, it is possible to try and contain the hazard to a given area and thus prevent any further spread. In containment, the objective is to protect the nearby areas, either inside the country in question or in neighbouring countries (Council of Europe, 2003). If this is also not possible, the final alternative is to control the hazard such that its population size, density or prevalence remains below some threshold level.

Although, for instance, the guiding principles of the United Nations Convention on Biological Diversity (CBD) advocate eradication as the next best thing if prevention fails, in the context of invasive species very few eradication programmes have been carried out in Europe. The reasons for this include inadequate national laws, unclear responsibilities among authorities and opposition by animal rights groups (Genovesi, 2005). In contrast, for animal diseases the case is somewhat different. Heath (2006) points out that all high-income countries have eradicated all new animal diseases provided that there has been political will to do so. For the poorer countries this is not the case, as private producers are not necessarily interested in diseases that cause large trade disruptions but where production losses may be modest. In other words, there is a divergence between private and social incentives.

In addition, invasions that are not targeted immediately when a hazard is first encountered and thus become widespread can be extremely costly to eradicate (see e.g. Cowan, 1992; Genovesi, 2005). Hence eradication is often feasible only when the size of the invading population is relatively small and it is geographically restricted (Council of Europe, 2003). Invasion dynamics are not the only issue to account for, however. Perrings (2000) establishes the conditions under which allowing establishment and spread of invasive species is optimal and emphasises that the relative costs and benefits of native and non-native species are important.

The society should explicitly account for the trade-off between present expenditures to protect ourselves from the invasion, and future expenditures to control or reduce the damage from the few harmful invasions (Jensen, 2002). For instance, most studies on foot and mouth disease are argued to concentrate on post-outbreak disease management, and less attention has been paid to pre-event surveillance and detection. No studies have been conducted that assess the benefits of surveillance and detection relative to associated damage (Elbakidze and McCarl, 2005, see also Born et al., 2005).

Several economic studies exist where one management strategy (often the current strategy) is compared to an alternative strategy. Wider comparisons of various alternative strategies are much less common. Examples of comparisons for more than two strategies include, for instance, McInerney and Kooij (1997), and Rich and Winter-Nelson (2007). The most common strategy options that are evaluated include some sort of preventative action versus reactive control. These strategies have been studied by, for instance, Burnett et al. (2007), Fernandez (2008), Persson and Jendteg (1992), Maijala et al. (2005), Cembali et al. (2003), Ranjan et al. (2008), Cook et al. (2007), and Heikkilä and Peltola (2007).

Other economic strategy comparisons that have been undertaken include, for instance, eradication versus control (Eiswerth and van Kooten, 2002; Olson and Roy, 2002; Andersson et al., 1997), eradication versus containment (Cacho et al., 2008; Sharov and Liebhold, 1998; Sharov, 2004), detection versus control (Mehta et al., 2007), control versus no control (Fasina et al., 2007), vaccination versus alternatives (Mukhebi et al., 1999; Kobayashi et al., 2007; Berentsen et al., 1992), regionalisation versus no regionalisation (Paarlberg et al., 2007), and eradication with restoration versus adaptation (Zavaleta, 2000).

In most cases the strategy alternatives are seen as substitutes that are compared against each other. Much more rarely has a study incorporated strategy choices as complements in order to determine the optimal mix of strategies. Such a study was undertaken for prevention and control by Burnett et al. (2008) to determine the optimal intertemporal allocation of resources. Also, Pifafi and Rousmasset (2007) provide an integrated framework where optimal prevention is combined with optimal pest removal. They show how optimal prevention depends on minimised costs resulting from the failure of 
prevention, including damage costs. Other studies on complementary strategies include Burnett et al. (2006), Leung et al. (2002), and Kim et al. (2005).

The methods employed in these assessments show a wide (but thin) variety including, for instance, optimal control theory (Burnett et al., 2007), Monte Carlo simulation (Heikkilä and Peltola, 2007; Russell et al., 2006; Niemi et al., 2008), linear programming (Hastings et al., 2006) and game theory (Fernandez, 2008). Objects of the studies include a wide variety of different biological hazards.

The optimal management strategies have been found to vary in space and time. Location has been found to matter for the largest cost components (Persson and Jendteg, 1992) as well as for optimal strategies (Burnett et al., 2007). For instance, James and Rushton (2002) argue that in many studies (Netherlands, Italy, Germany, etc.) it has been shown that eradication of foot and mouth disease is more economical than vaccination in Europe, whereas in developing countries stamping out seems not to be feasible or desirable. Similarly, it is argued that in Nigeria, even at the expense of loss of export markets, the best method for H5N1 control is vaccination (Fasina et al., 2007). The optimal strategy has also been found to be time-varying (Hastings et al., 2006) as well as to depend on species characteristics (damage, growth rate) and varying from do nothing to a high level of effort (Mehta et al., 2007).

Costs that should be included in a thorough economic assessment of biosecurity management strategies, and that have variedly been included in the strategy assessments, comprise (after Burnett et al., 2007; Persson and Jendteg, 1992; Niemi et al., 2008; Cembali et al., 2003; Mehta et al., 2007; Kobayashi et al., 2007; Fasina et al., 2007): (1) infrastructure and administration cost; (2) search and detection cost; (3) cost of pest or disease control; (4) illness treatment costs (human, animal); (5) illness costs (human); (6) loss of productive capacity (human, animal, plant, environment); (7) cost of business interruption and demand switches; (8) price movements; and (9) compensation payments and other income transfers.

When the distribution of costs and benefits of management strategies has been studied, it has generally been found to be very uneven. For instance, Mukhebi et al. (1999) find that $91 \%$ of the costs of heartwater disease are borne by the commercial farmers and Cembali et al. (2003) find that the nurseries who pay for the analysed virus prevention programme receive benefits of $\$ 0.5$ million ( $0.2 \%$ of total benefits), whereas growers and consumers who do not pay for the programme benefit $\$ 80$ million and $\$ 147$ million, respectively. Similar findings are made by Gutrich et al. (2007) in the case of fire ant in Hawaii as well as Mangen and Burrell (2003) in the case of classical swine fever in the Netherlands. Also, Niemi and Pietola (2004) note that in the case of pig diseases, the privately optimal solution is not necessarily the one that is socially desirable.

Uncertainty is more and more included in the assessments in this category, but treatments of it as well as the implications of uncertainty differ widely. Uncertainty is important to account for, because it is often related to the outcome of the events, although not in a straightforward manner. It has, for instance, been found that uncertainty in initial population size (Mehta et al., 2007) and in timing and nature of invasion
(Ranjan et al., 2008) has a substantial impact on the optimal strategy. On the other hand, Russell et al. (2006) find that in $60 \%$ of the cases considered in their study, the best policy did not change when uncertainty was introduced. Similarly, Jensen (2002) finds that his conclusions hold regardless of whether the costs are known for certain or only in distribution.

\section{Example of category 3a problem framing: prevention versus adaptation}

Prevention (or mitigation, avoidance, pre-emptive control) and adaptation (or reactive control, treatment, amelioration) are perhaps the most widely studied strategy alternatives. There is a general agreement that on most occasions preventative actions are the best strategy, given the uncertainties involved and the difficulties in eradicating most species and diseases reactively. For instance, Fernandez (2008) finds that co-operative and preventative abatement is optimal to all other strategies. This approach is put forward by, for instance, the intergovernmental scientific advisory body established by the CBD (Perrault and Carroll Muffett, 2001) as well as the European Union in relation to many animal diseases.

For instance, Leung et al. (2002) use stochastic dynamic programming to study how to devote resources between prevention and control efforts given uncertain invasion events. They apply their general model to the case of zebra mussel (Dreissena polymorpha) - an aquatic species that spread from Europe in ship ballast and has subsequently spread rapidly within the United States. The species damages power plants by blocking their water intake pipes. The authors show that the society could be made better off by spending up to 0.3 million dollars annually to prevent the invasion of a single hypothetical lake with a power plant. This figure can be compared with the 0.8 million dollars that the US Fish and Wildlife Service spent on all aquatic invaders in all US lakes in 2001 (Leung et al., 2002).

The costs of prevention comprise, for instance, costs of surveillance, labelling, import restrictions, compensation payments and post-monitoring. Often the benefits of not having the pest around outweigh these costs, but this is by no means inevitable (Mumford, 2002). In such a case, continued efforts to prevent the hazard from invading consume the limited resources and may possibly lead to other, more dangerous, hazards not being targeted with sufficient resources. Several European countries have, for instance, voluntarily renounced their protection systems regarding specific species (Heikkilä, 2006). On at least one occasion cost-benefit analysis has been in favour of denouncing a preventive policy (MacLeod et al., 2005).

Elbakidze and McCarl (2005) show that optimal preevent detection depends on likelihood of disease introduction, spread rate, relative costs, ancillary benefits and effectiveness of mitigation. For slowly spreading diseases, investment in pre-outbreak activities is optimal only for very high outbreak probabilities. A somewhat similar conclusion is reached by Burnett et al. (2008), who suggest that it would be worthwhile spending money on finding small populations rather than to 
attempt to prevent all future introductions. Of course, investments in prevention and adaptation are not necessarily mutually exhaustive. For instance, Kim et al. (2005) show that prevention and control are complementary when the population size is small, but become substitutes as the population size increases.

In addition to biological factors, relative costs and benefits, and effectiveness of mitigation there are three further factors affecting the strategy choice between prevention and adaptation. The first of these is uncertainty. Mahul and Gohin (1999) note that if there is little uncertainty it may be worthwhile to wait and see until uncertainty is resolved. Thus, in practice adaptation may be preferred over prevention because of uncertainty. The relationship between resources invested in prevention and benefits thus acquired is very uncertain. Risk in this context has two dimensions: (1) the probability and level of damage associated with the biological hazard; and (2) the opportunity cost of resources spent on prevention of the biological hazard, which may or may not make an entry attempt. Finnoff et al. (2007) show that a risk-averse (i.e. precautionary) manager is likely to invest less resources in prevention and more in adaptation because the return for the investment in prevention is less certain. Hence adaptation may appear as the less risky management strategy, even though it is often also the more expensive one (Finnoff et al., 2007, see also Shogren, 2000 and Perrings, 2005).

The second additional factor is human adaptation, which is important to take into account when considering the merits of adaptation. In a relatively early theoretical analysis, Butler and Maher (1986) argue that by not taking the actions by the victims of an externality into account, the society may end up devoting too many resources to prevention. Similarly, Margolis et al. (2005) show that unaccounted for private actions result in the regulator choosing a level of prevention (tariff level) that is larger than is socially optimal. Shogren (2000) argues that once we acknowledge that people do adapt, assuming otherwise may lead to biased results.

Finally, the chosen objective of strategy optimisation may affect the desirability between prevention and adaptation. Barrett and Segerson (1997) note that besides Pareto efficiency there are other objectives that policies may seek, including minimising damage subject to a budget constraint or minimising expenditure subject to a given damage level. They show that under these constrained objectives some factors affecting the relative desirability of prevention versus adaptation may affect the decision differently from how they function under Pareto efficiency. For instance, in contrast to Pareto efficiency, under a budget constraint a reduction in uncertainty about the effectiveness of adaptation may lead to a decrease in the level of prevention and an increase in the level of adaptation. Adaptation may also be preferred if the government pays for prevention and has a strict budget constraint. Therefore, if public money can be more productively invested in preventing entry by Hazard B, it may be that Hazard A is best controlled through adaptation paid for by producers, although prevention might also in this case be a socially optimal strategy.

Lichtenberg and Penn (2003) - albeit in relation to chemical hazards - argue that prevention is not always the most cost-efficient strategy in the case of agricultural pollution. This is so when there are multiple sources of emissions, multiple sites affected and a widely adopted precautionary approach to uncertainty. More generally, based on the above discussion it might be argued that adaptation is relatively more attractive when: (1) the invasion probability is relatively low and the probable damage modest; (2) the effectiveness of adaptation is high; (3) adaptation strategies and incentives of individuals are taken into account; and (4) the decision-maker dislikes uncertainty regarding the outcome of the policies. Furthermore, as Waage and Mumford (2008) suggest, perhaps a greater focus should be put on building resilience to invasion (through, for instance, developing pest and disease resistance and vaccines as well as through diversification of production) rather than building walls around the protected systems.

\subsubsection{Category $3 b$ : cost-efficiency of management methods}

Cost-efficiency of different management methods within strategies is the next category reviewed here. Here, the management strategy (and perhaps the method) has already been agreed upon, but the question is how to utilise it most efficiently. This includes questions such as what is the economically optimal eradication radius in a disease outbreak, when and to what extent should vaccination be used, how much pesticide should be used to control a plant pest, and so forth. Separate questions also include how the cost-effectiveness of the management method is affected by, for instance, resistance to chemical control substances and antibiotics or changes in the natural or production environment.

Studies in this category are numerous. To provide some examples, there have been studies on cost-effectiveness of alternative prevention measures (De Vos et al., 2005), stamping out and vaccination alternatives (Schoenbaum and Disney, 2003; Mangen et al., 2002; Mangen et al., 2001; Saatkamp et al., 2000), surveillance methods (Prattley et al., 2007; Powell et al., 2008; Saatkamp et al., 1997; Klinkenberg et al., 2005) and different food safety procedures (Jensen et al., 1998; Goldbach and Alban, 2006). As there are many studies in this category, various methods and study targets exist. The methods utilised include, for instance, stochastic dynamic programming (Houben et al., 1994), stochastic state transition models (van der Gaag et al., 2004; Schoenbaum and Disney, 2003), portfolio theory (Prattley et al., 2007), the scenario tree model (De Vos et al., 2005), the gravity model (Otsuki et al., 2001) and generalised linear mixed models (Chriél et al., 1999).

As an example of category $3 \mathrm{~b}$ research methodology, consider optimal control. Using a traditional cost-benefit analysis it is possible to analyse a set of possible policies; for instance, the cost-efficiency of using a depopulation ring of 1,3 or 5 kilometres, but it is not possible to analyse what would be the optimal radius of the depopulation ring (Kobayashi et al., 2007). To answer this, some sort of optimisation method is needed. Optimal control is a traditional method in resource economics and it is therefore not surprising that there are several applications to biosecurity. The application may be 
directly to optimal pest or disease control (Dehnen-Schmutz et al., 2004; Christiaans et al., 2007) or to, for instance, optimal feeding policy under animal movement restrictions (Niemi and Pietola, 2004). The control strategies have also been studied by Hilje and Stansly (2008), Johansson et al. (2005); Buhle et al. (2005), and Ross and Pollett (2007). The optimal control policy has been found to depend on, for instance, the available annual budget (Taylor and Hastings, 2004), policy- and sectorspecific factors (Breukers, 2007) and on the production function (Christiaans et al., 2007). It has also been found that the cost-effectiveness is reduced if all firms do not adopt the control procedure (van der Gaag et al., 2004) and that the adopted framework (for instance, expected utility) impacts on the optimal policy (Horan et al., 2002).

The study objects range from individual invasive species such as koalas (Ross and Pollett, 2007), Bemisia tabaci (Hilje and Stansly, 2008) and greenhouse whitefly (McKee et al., 2008) to marine invasive species (Fernandez, 2008; Jones and Corona, 2008), ornamental garden plants (Dehnen-Schmutz et al., 2004), and individual species in specific countries (Blignaut et al., 2007). In the context of animal diseases the applications vary from individual diseases such as classical swine fever (De Vos et al., 2005) or hypothetical foot and mouth disease (Schoenbaum and Disney, 2003) to assessments of management systems for multiple diseases such as the pig identification and recording system in Belgium (Saatkamp et al., 1997) or hog producer income under contagious animal disease quarantine (Niemi and Pietola, 2004). In the context of zoonotic diseases and human health the applications include, for instance, salmonella (Goldbach and Alban, 2006; Chriél et al., 1999; van der Gaag et al., 2004; Jensen et al., 1998) and aflatoxin regulation (Otsuki et al., 2001).

Similarly to studies on the choice of management strategy, here a convergence between privately and socially optimal methods has also been found in several studies. Hilje and Stansly (2008) find that the method that is overall most economic (plastic cover) was also too expensive for the resourcepoor farmers. Thus, although, for instance, Goldbach and Alban (2006) argue that it is the relative profitabilities of alternatives rather than the absolute values that are important, they are of little relevance if the private agents have no incentives to pay for either method. De Vos et al. (2005) point out that in determining the optimal method, one should account for the cost effectiveness but also for: (1) ease of implementation (small or large investments, are significant adaptations required); (2) allocation of costs and benefits (some measures may be too costly for private producers); (3) the cost-benefit ratio; and (4) attributable costs (beneficial side effects, e.g. reduce the probability of other hazards).

\subsubsection{Category 3c: choice of policy instruments}

In addition to considering the preferred control strategy (e.g. prevention) and preferred level of intervention, we are also interested in how that control strategy should be achieved. Should we, for instance, use command and control instruments to ban certain types of imports altogether, or should we per- haps tax the imports in a risk-based manner, or maybe we should resort to delivering information on the risks to all parties involved. Naturally, some policy instruments are complementary (e.g. information), whereas others can be seen as substitutes (e.g. trade ban and import tariffs cannot apply to the same products at the same time).

Economic analysis and development of policy instruments is one of the most promising areas in which economics can contribute to better biosecurity. For instance, Jones and Corona (2008) show that in the context of aquatic invasive species an ambient tax induces both short-run and long-run efficiency with minimal information requirements, and Blignaut et al. (2007) discuss the structure, size and distribution of a charge to eradicate invasive plants in South Africa over the next 25 years. Dehnen-Schmutz et al. (2004) show that a subsidy on control costs is the most effective and reliable method, and that increases in direct grants or in control volunteer numbers are less effective. In contrast, Hennessy (2007) finds that losses are smaller when production is concentrated, but that subsidies to small producers may exacerbate overall losses.

Overall, literature on this theme has been expanding vastly over the past few years, but is still relatively thinly dispersed. Topics that have recently been covered include the polluter pays approach (Jenkins, 2001), ambient taxes (Jones and Corona, 2008), user charges (Blignaut et al., 2007), tradable risk permits (Horan and Lupi, 2005), control subsidies (Dehnen-Schmutz et al., 2004; Hennessy, 2007) and Pigovian taxes (Knowler and Barbier, 2005), as well as discussion on economic incentives in general (Fernandez, 2008). Gren (2008) provides a discussion on policies available for the control of invasive species.

\subsubsection{Example: biological hazards and import of goods}

The economics of biological hazards in relation to import of goods has been a topic of much research (e.g. Anderson et al., 2001; Oude Lansink, 2008) so we use it as an example of the types of studies conducted. When a particular good is proposed for import, there can be a screening of whether the good should be allowed for import or not. There has been some discussion on whether we would be better off ignoring the advice of the screening process or not (Smith et al., 1999; Caley et al., 2006). An empirical application of a similar question is provided by Keller et al. (2007), who assess when risk assessment is worth it compared to letting all species in. They apply their model to the Australian ornamental industry, assuming that the decision to import a species is irreversible. Over relatively short periods there is not much difference in the net present value of the two policies (screen or do not screen), but for longer time periods screening creates large positive values and the fixed costs of undertaking the risk assessments have a negligible impact on the results. The authors point out that since the World Trade Organization requires that SPS-based risk reduction strategies must produce net economic gains, their model can be used to demonstrate that.

Import risk assessments (IRAs) can be used to evaluate whether some imports should be prevented altogether in order 
to protect the society from the risk of imported diseases and pests. Examples are provided by studies on the risks posed by import of animals vaccinated against foot and mouth disease and their products (Sutmoller and Casas Olascoaga, 2003), import of marker-vaccinated animals (Breidenbach et al., 2007), and the risk of BSE through imported animals and their products in Japan (Sugiura et al., 2003). Adamson and Cook (2007) point out that even in Australia, where relatively many import risk assessments have been undertaken, economic assessments are often limited to either estimating (1) how much consumers would benefit if free trade was allowed or (2) the economic impacts if a given pest or disease reaches the country. They argue that little work has been done to combine these two, which would be important in order to obtain a truthful estimate of the total impacts.

For instance, Cook (2008) studies the case where Chilean table grape producers were granted access to Australian markets, but not to Western Australia, which is free of many pests present elsewhere in the country. The outcome of the study is that the mean expected production damage from also allowing access to Western Australia would be around AU $\$ 10.3$ million, whereas consumer benefits would be only AU $\$ 1.5$ million. Hence there is no reason to allow market access. However, preventing trade in exotic species that also have beneficial impacts is not necessarily economically desirable. Knowler and Barbier (2005) studied saltcedar (Tamarisk spp.) in the United States, and their results indicate that to achieve the social optimum, the mere presence of risk associated with imports does not warrant prevention of commercial sales of exotic plant species with beneficial effects for consumers. Similarly, Otsuki et al. (2001) suggest that less stringent regulation may increase trade flows and income. Instead of bans, Knowler and Barbier (2005) suggest the use of market instruments, including a Pigovian tax, to regulate the industry and protect the society from the associated risks. Prevention of entry and the associated trade instruments are also studied by Horan et al. (2002), Costello and McAusland (2003), McAusland and Costello (2004), Horan and Lupi (2005), and Margolis et al. (2005).

In addition to being a question of choosing the right policy instrument, import risk assessments can be seen as a special case of hazard ranking (Sect. 3.3), because although not necessarily conducted in order to compare different biological hazards, the procedure is often so standardised that it allows the comparison of hazards for which an assessment has been conducted. This is especially so if the IRA follows consistent methodologies. In many cases IRAs are based on established risk assessment procedures; for instance, the OIE import risk analysis framework or the EPPO guidelines, which are accepted by the World Trade Organization as a justification for actions that could also be considered artificial barriers to trade. Naturally, even if the general framework is standard, the different economic components vary within the studies (e.g. which valuation methods have been used and what effects have been taken into account). Hence the different studies may still not be entirely comparable.

For goods and shipments accepted for import, regulation may still be necessary through, for instance, inspections or tariffs, which are meant to reduce the probability of harmful organisms entering the country. However, the inspection services are under pressure from the increasing import quantities as well as in many cases due to resource constraints. Further complications arise from the diverse range of imported goods and their origins. For instance, Costello et al. (2007) show that the risk varies by trading partner and that the cumulative number of introductions from a region is a concave function of imports. As for many countries it is vital to maintain an appropriate level of protection, a typical question in economic studies is how to establish efficient border protection measures.

The basic premise for many of the studies on optimal inspection strategies is that there is a number of shipments coming to a port, the probability that a crate within the shipment is infested is unknown, and the inspector has to decide how to allocate the scarce surveillance resources; for instance, how many crates to inspect and in which shipments, and how long a time should be used for the inspection. Research along these lines has been conducted by, for instance, Moffitt et al. (2008), Surkov et al. (2008), Batabyal and Beladi (2006), and Batabyal and Nijkamp (2006). An empirical assessment is provided by Work et al. (2005), who evaluate the effectiveness of monitoring the arrival of insect species in the United States through four cargo pathways.

As for tariffs, Paarlberg and Lee (1998) discuss the link between import tariffs and the level of health risk from imports with special reference to the foot and mouth disease. They show that the optimal level of tariffs is very sensitive to the risk of importing a contaminated product, as well as to the expected spread rate of the disease. More specifically, the infection rate of the imported goods has been shown to increase the optimal tariff level (McAusland and Costello, 2004). However, at very high levels of infection the optimal level of inspections decreases, possibly all the way to the point of no inspections. This occurs when most incoming goods are infected, and it is better to let them in without any inspections and instead charge a high tariff equal to the expected damage (McAusland and Costello, 2004).

However, too high a tariff is also socially sub-optimal. Margolis et al. (2005) show that private actions result in the regulator choosing a higher tariff level than is socially optimal. Further, tariff escalation (the more processed the imported good, the higher the charged tariff) has been shown to increase the probability of hazard introduction (Tu et al., 2008). This is because it results in trade being biased towards primary commodities (with higher probability of harmful organisms) as opposed to processed products. Tu et al. (2008) show that a reduction in tariff escalation would increase allocative efficiency and reduce damage from invasive species.

In a case of unlimited research resources, the studies would consider the questions regarding whether to import or not, how to inspect and place tariffs optimally, how to control the species and disease if it arrived and escaped inspections, and so on, and then compare all possible combinations with each other to determine the optimal course of actions in the face of uncertainty. However, this is not practical in reality, and hence the questions are divided into smaller manageable questions. 
Table I. Examples of individual invasion cost estimates.

\begin{tabular}{|c|c|c|c|}
\hline Level & Target & Annual cost estimate & Reference \\
\hline Multi-country multi-hazard & $\begin{array}{l}\text { Invasive alien species in } 6 \text { countries } \\
\text { (USA, UK, Australia, South Africa, } \\
\text { India and Brazil) }\end{array}$ & USD 314 billion & Pimentel et al., 2001 \\
\hline \multirow{5}{*}{ Single country multi-hazard } & Invasive alien species in China & $\begin{array}{l}\text { USD } 14.5 \text { billion of which } 83.4 \% \text { indirect. } \\
\text { Equivalent to } 1.4 \% \text { of Chinese GDP }\end{array}$ & Xu et al., 2006 \\
\hline & Invasive alien species in Canada & CAD 13-34 billion & Colautti et al., 2006 \\
\hline & Weeds in Australia & AUD 4 billion & Martin, 2003 \\
\hline & 35 animal diseases in UK & $\begin{array}{l}\text { Economically most important are mastitis for } \\
\text { cattle ( } 179.7 \text { million), enzootic abortion for } \\
\text { sheep ( } £ 23.8 \text { million), swine influenza for pigs } \\
\text { ( } £ 7.7 \text { million) and salmonellosis for poultry } \\
\text { ( } 104.7 \text { million) }\end{array}$ & Bennett and Ijpelaar, 2003 \\
\hline & South Africa fynbos & $\begin{array}{l}\text { Value from R19 million under low valuation } \\
\text { and poor management to R300 million under } \\
\text { high valuation and good management. Cost of } \\
\text { clearing alien plants } 0.6-5 \% \text { of the ecosystem } \\
\text { value }\end{array}$ & Higgins et al., 1997 \\
\hline \multirow{3}{*}{ Multi-country single hazard } & $\begin{array}{l}\text { H5N1 avian influenza on interna- } \\
\text { tional markets }\end{array}$ & $\begin{array}{l}\text { First year market loss USD } 1.4 \text { billion to } 14 \text { bil- } \\
\text { lion, depending on scenario }\end{array}$ & $\begin{array}{l}\text { FAO/CTD, 2006; Food Outlook, } \\
2006\end{array}$ \\
\hline & Asian longhorn beetle in Europe & $\begin{array}{l}90 \% \text { of wood in infested areas could lose half } \\
\text { of its value }\end{array}$ & MacLeod et al., 2002 \\
\hline & $\begin{array}{l}\text { Salmonellosis in England and Swe- } \\
\text { den }\end{array}$ & $\begin{array}{l}\text { For cost of illness (control cost) } 2.6 \text { pence }(2.0 \\
\text { pence) per chicken in England and Wales and } \\
0.5 \text { pence }(10.8 \text { pence) per chicken in Sweden }\end{array}$ & Persson and Jendteg, 1992 \\
\hline
\end{tabular}

It is, as always, up to the researchers to place the research in the wider framework.

\subsection{Category 4: cost estimates of disease outbreaks and species invasions}

The final category discussed here includes the evaluations of individual invasion events or policies. There are hundreds of estimates of the damage caused by individual species or diseases, for both real invasions as well as for simulated ones. Some of these are related to specific countries or groups of countries, some to specific groups of species, and some to specific pests and diseases. They may be based on materialised damage from real invasions or on simulation of potential damage, and incorporate various and varying cost elements, making any comparison between the studies laborious or impossible. Some examples are provided in Table I.

Figure 3 presents a collection of published empirical economic biosecurity studies by type and target country. Only countries for which more than one study was readily available are presented in the figure. The results were obtained with an internet search, as well as through the author's personal collection of papers. Only studies in which there is an empirical application to a real-life situation were included in the sample. Altogether, there are 231 studies in the sample. Although the literature search has not been exhaustive, general trends are easy to observe. The publications are divided such that $39 \%$ 
Publications

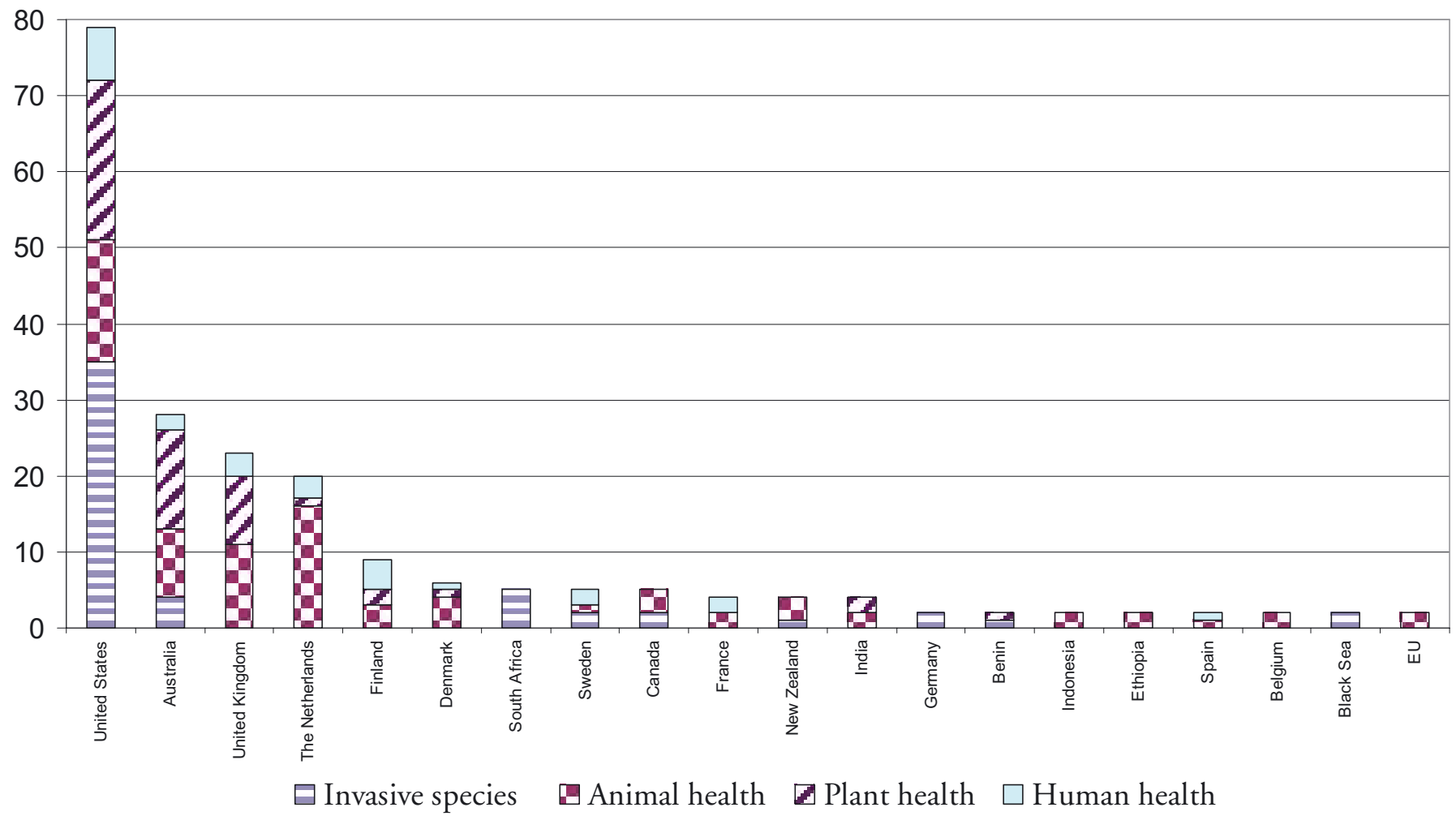

Figure 3. Reviewed biosecurity studies by category and country of application.

deal primarily with animal health, $25 \%$ with plant health, $11 \%$ with human health (only zoonotic diseases and biological food safety included in the sample) and $25 \%$ with environmental health (invasive alien species detrimental to the environment in general). Of course, sometimes it is difficult to precisely differentiate between plant health and environmental health.

The United States is the country in which most applications take place (35\% of all studies in the sample), followed by Australia (13\%), the United Kingdom (10\%) and the Netherlands $(9 \%)$. Together these four countries represent two-thirds of all studies. However, the domination of the US, European Union and Australia in these figures is not surprising considering that they are all industrialised countries who produce and export large quantities of agricultural products.

It also appears that many assessments in the United States (44\% of all US studies) and South Africa (100\%) relate to invasive species that pose a threat particularly to the environment. In contrast, in Australia (46\% of Australian studies) the emphasis is somewhat more on plant health and in the Netherlands $(80 \%)$ and Denmark $(67 \%)$ on animal health, which is not a big surprise, given the relative importance of animal production in these two countries. In the United Kingdom, plant health constitutes about $39 \%$ and animal health about $48 \%$ of all studies.

These trends are similar to those found in a meta-analysis of the ecological invasion literature. Pysek et al. (2008) analysed 2670 papers dealing with 892 invasive species, and showed that all major groups are well studied, but most information on invasion mechanisms is based on a limited number of invaders. They also show a strong geographical bias, with Africa and Asia understudied and America and Europe having the highest number of both species studied and studies published. Almost half of all the invasive species and more than half of all studies analysed by Pysek et al. (2008) relate to North America. They also note that the position of Africa is largely determined by South Africa, representing two-thirds of research on the continent. The fact that these trends reflect on the economic literature is understandable, given that empirical applications in biosecurity economics are to a large extent dependent on availability of biological data or expertise.

Pysek et al. (2008) also point out that only 49 species were subject to 10 studies or more, the most studied being zebra mussel and Argentine ant. A similar conclusion of most research concentrating only on a few species was reached in the context of plant health by the EUPHRESCO project in the European Union (Buzy et al., 2007).

The publications were also classified by journal and year (Figs. 4 and 5). Figure 4 demonstrates that for animal health economics Preventive Veterinary Medicine is the primary journal of publication. On the other hand, for invasive species economics Ecological Economics is the top choice, followed by the Journal of Environmental Management and Biological Invasions. For plant health economics the most popular choice is Crop Protection, again followed by the Journal of 
Publications

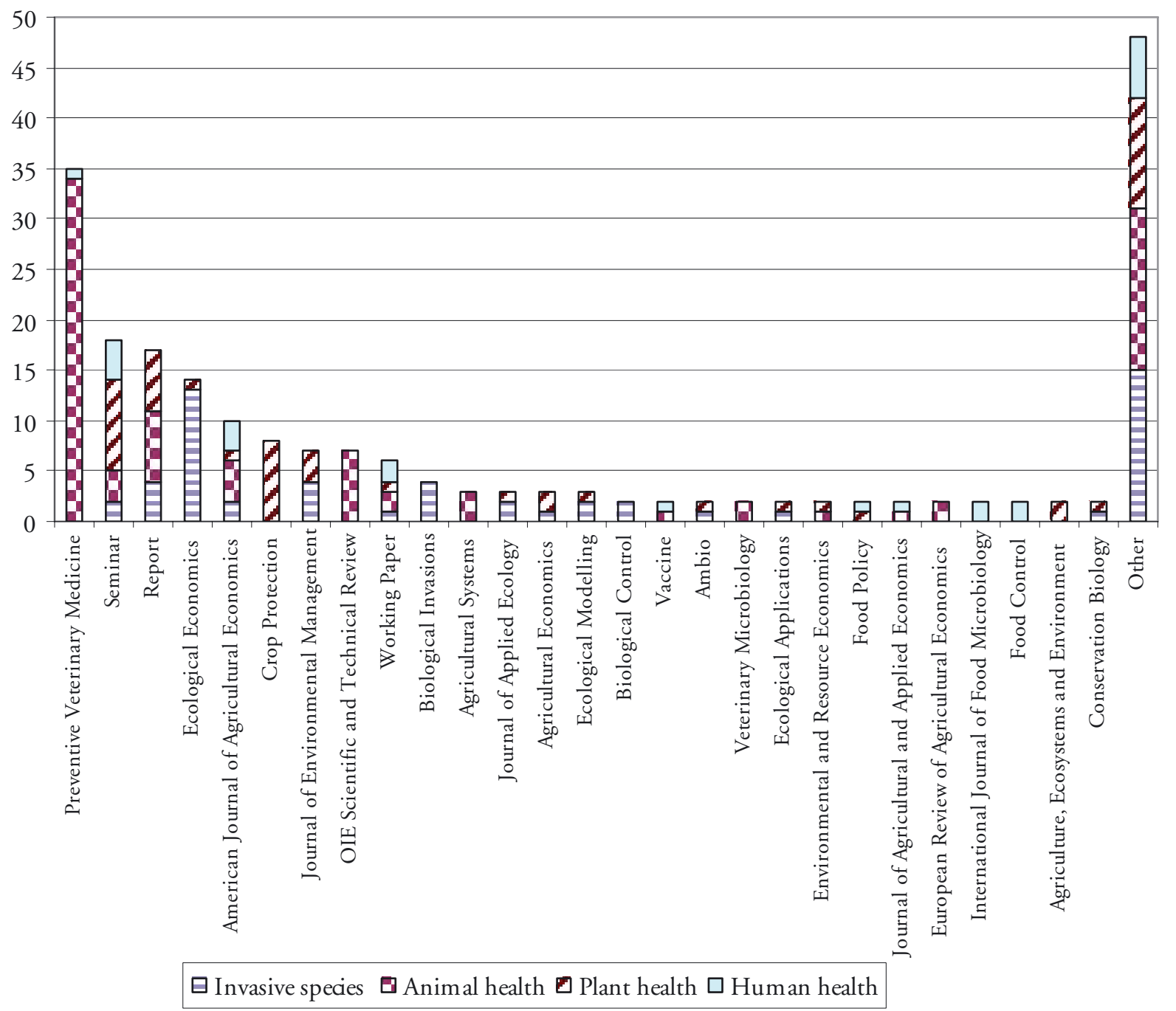

Figure 4. Reviewed biosecurity studies by category and journal.

Environmental Management and Agricultural Economics. It is also remarkable how thinly the studies are distributed over a wide variety of journals. In the sample of 231 studies there were 48 journals that contributed one paper each.

Just over $20 \%$ of the papers were published in economic journals, the major economic journals being Ecological Economics (14 studies), the American Journal of Agricultural Economics (10), Agricultural Economics (3) and Environmental and Resource Economics, the Journal of Agricultural and Applied Economics and the European Review of Agricultural Economics (2 each). Some $10 \%$ were in primarily natural science journals, the main journals being Ecological Modelling (3 studies), and Vaccine, Veterinary Microbiology, Ecological Applications and the International Journal of Food Microbiology ( 2 each). This also means that most papers were published in fairly interdisciplinary journals, as depicted in Figure 4.

Figure 5 demonstrates that the volume of papers in the sample has increased gradually over the years and the field is grow- ing steadily. It also seems that the number of papers on animal health economics has remained relatively stable over the past 15 years or so, while the number of papers on economics of invasive species has increased rapidly.

\section{DISCUSSION}

It seems apparent that the broader the context (categories 1 and 2), the less economic research there is. Category 1 is virtually not studied at all, and category 2 is studied very little, with the exception of the risk ranking studies. These, however, would be likely to benefit from more rigorous economic considerations. In category 3 there are numerous studies concentrating on specific questions and employing a wide but relatively thin range of methodologies (see, e.g., Oude Lansink, 2008; Perrings et al., 2000). In category 4, a substantially greater number of studies exists, but these would benefit from 
Publications

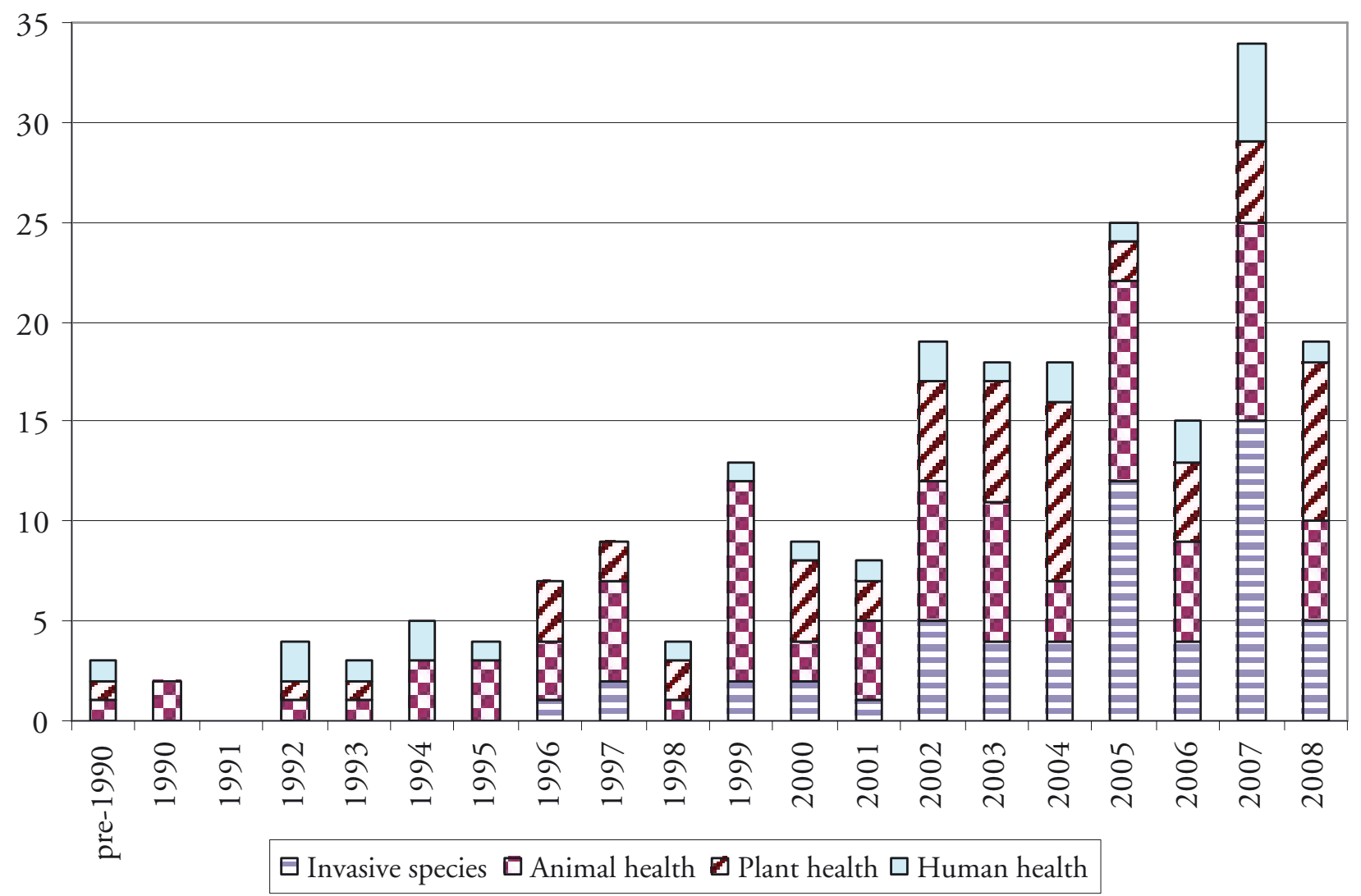

Figure 5. Reviewed biosecurity studies by category and year of publication.

some standardisation of approaches. The fact that in many assessments there are no clear common methods or frameworks (applying to both the methodologies used as well as to the types of costs included), cross-study comparison is relatively difficult. Yet, such comparison would be needed when deciding on how to allocate the available resources of the society. Of course, as mentioned earlier, the categories identified here are separated sections from the larger framework, which is seldom evaluated in individual papers, as demonstrated by the example of studies on import of goods.

It has been pointed out that two major contributions of economics to biosecurity discussion are, on one hand, to provide estimates on the impacts of invasions (category 4 in this paper) and hence improve the cost effectiveness and efficiency of control (category $3 \mathrm{~b}$ ), and on the other hand, to develop economic sanitary and phytosanitary measures (category $3 \mathrm{c}$ ) (Evans et al., 2002). Shortle (2007) emphasises the importance of economic research to the development of effective and efficient management strategies (category $3 \mathrm{a}$ ) as well as to understanding the co-evolution of economic and ecological systems. It is worthwhile to emphasise the role of economics in resource allocation and its use to determine how to prioritise different hazards, their management strategies, methods and policies.

Environmental and health impacts are notoriously difficult to value. However, as pointed out by Adamson and Cook
(2007), even quantification of the area of impact and a list of native species at risk (and the level of risk) would be informative. It has also been suggested that the value of modelling is the actual process of working through the problems and issues rather than the identification of a final solution (Rushton and Upton, 2006). Modelling helps in conceptualising and thinking through complex problems analytically. In principle, for valuation of the effects of invasions or biosecurity policies almost any valuation method available in the economic literature is available. However, given the fact that we are dealing with thousands or tens of thousands of individual biological hazards, it seems clear that no nation has enough resources to undertake thorough studies of them all. Hence development of general assessment protocols, frameworks and prioritisation schemes for assessing the risk associated with biological hazards seems like a good candidate for a top priority research area.

The distribution of costs and benefits is an important issue, which is already beginning to affect the current animal health policies in the European Union. Also, in other contexts the distribution of costs and benefits has been found to be very uneven, as discussed in Section 3.4. Yet having a clearer idea about this would help in understanding the private incentives and subsequently in designing appropriate policies to account for the convergence of social and private interests. As 
Hennessy (2007) notes, designing public policies in biosecurity requires a clear understanding of the failure in private incentives.

Another challenge, as highlighted by Gramig and Wolf (2007), is that many studies are done on a disease-by-disease basis, yet preventative actions often protect against multiple diseases. As they point out, preventative actions against multiple hazards can be thought of as either multi-product outputs of individual management practices, or as either positive or negative input externalities. Given that prevention is generally acknowledged to be a cost-effective strategy, it is somewhat surprising how few assessments there are of the ongoing costs and cost-efficiency of prevention at the farm level. The government-level costs are often known (although not necessarily published), but we often know very little about the farm-level costs and their impact on the level of prevention (Siekkinen et al., 2008). This is important, because these costs materialise every year, regardless of whether there is a pest or disease outbreak or not.

To conclude, we suggest the following top five priority areas (in no particular order) for study: (1) development of sophisticated economic policy instruments to mitigate biological hazards; (2) design of rigorous economic prioritisation frameworks to guide both academic research and government policies; (3) clearer understanding of the distribution of biosecurity impacts and the associated private incentives; (4) establishing a closer link between the costs and methods of prevention, and the economic risk; and (5) the role of human behaviour in biosecurity and how that behaviour can best be directed. We might also wish to find out to what extent lessons learned in some fields of biosecurity are applicable for other hazards, areas or circumstances. In general, it seems warranted to search for holistic approaches - for instance, determining simultaneously the optimal strategy, optimal management methods and optimal policies to achieve the targets - and doing so for the right hazards. No small task.

\section{REFERENCES}

Adamson D., Cook D. (2007) Re-examining economic options for import risk assessments, Murray Darling Program Working Paper M07\#3, The University of Queensland, Australia.

Andersson H., Lexmon Å., Robertsson J.-Å., Lundeheim N., Wierup M. (1997) Agricultural policy and social returns to eradication programs: the case of Aujeszky's disease in Sweden, Prev. Vet. Med. 29, 311-328.

Anderson K., McRae C., Wilson D. (2001) The economics of quarantine and the SPS agreement, Centre for International Economic Studies and AFFA Biosecurity Australia, Adeleide and Canberra.

Barrett J., Segerson K. (1997) Prevention and treatment in environmental policy design, J. Environ. Econ. Manager. 33, 196-213.

Batabyal A.A., Beladi H. (2006) International trade and biological invasions: a queueing theoretic analysis of the prevention problem, Eur. J. Oper. Res. 170, 758-770.

Batabyal A.A., Nijkamp P. (2006) Some probabilistic attributes of inspection policies in alien species management, Ecol. Econ. 60, 5-8.
Bennett R., Ijpelaar J. (2003) Economic assessment of livestock diseases in Great Britain, Final Report to the Department for Environment, Food and Rural Affairs, 19 September 2003.

Bennett R., Ijpelaar J. (2005) Updated estimates of the costs associated with thirty four endemic livestock diseases in Great Britain: A Note, J. Dairy Res. 66, 455-459.

Berentsen P.B.M., Dijkhuizen A.A., Oskam A.J. (1992) A dynamic model for cost-benefit analyses of foot-and-mouth disease control strategies, Prev. Vet. Med. 12, 229-243.

Bermejo M., Rodríquez-Teijeiro J.D., Illera G., Barroso A., Vilà C., Walsh P.D. (2006) Ebola outbreak killed 5000 gorillas, Science 314, 1564.

Biosecurity Council (2003) Tiakina Aotearoa. Protect New Zealand: the biosecurity strategy for New Zealand. Biosecurity Council. New Zealand, available online at http://www.biosecurity.govt.nz/files// bio-strategy/biostrategy.pdf.

Blignaut J.N., Marais C., Turpie J.K. (2007) Determining a charge for the clearing of invasive alien plant species (IAPs) to augment water supply in South Africa, Water SA 33, 27-34.

Born W., Rauschmayer F., Bräuer I. (2005) Economic evaluation of biological invasions - a survey, Ecol. Econ. 55, 321-336.

Breidenbach M.J., Engels M., Griot C., Stärk K.D.C. (2007) Quantitative risk assessment regarding the import of marker-vaccinated animals, A poster presented at the Annual Conference of the Society for Veterinary Epidemiology and Preventive Medicine (SVEPM), Helsinki/Espoo, Finland. 28-30 March 2007.

Breukers A. (2007) Bio-economic modelling of brown rot in the Dutch potato production chain, $\mathrm{PhD}$ thesis, Wageningen University, The Netherlands.

Buhle E.R., Margolis M., Ruesink J.L. (2005) Bang for buck: costeffective control of invasive species with different life histories, Ecol. Econ. 52, 355-366.

Burnett K., Kaiser B., Roumasset J. (2007) Economic lessons from control efforts for an invasive species: Miconia calvescens in Hawaii, J. For. Econ. 13, 151-167.

Burnett K., Kaiser B., Pifafi B.A., Roumasset J. (2006) Prevention, eradication, and containment of invasive species: illustrations from Hawaii, Agric. Res. Econ. Rev. 35, 63-77.

Burnett K.M., D’Evelyn S., Kaiser B.A., Nantamanasikarn P., Roumasset J.A. (2008) Beyond the lamppost: optimal prevention and control of the brown tree snake in Hawaii, Ecol. Econ. 67, 66-74.

Butler R.V., Maher M.D. (1986) The control of externalities: abatement vs. damage prevention, Southern Econ. J. 52, 1088-1102.

Buzy M., Marzin H., Anthoine G., Moens M., Inmand A. (2007) EC Sixth Framework ERA-NET Project EUPHRESCO, Report on the Mapping and Analysis of national Phytosanitary (Quarantine/Regulated Plant Health) Research Programmes.

Cacho O.J., Wise R.M., Hester S.M., Sinden J.A. (2008) Bioeconomic modeling for control of weeds in natural environments, Ecol. Econ. $65,559-568$.

Caley P., Lonsdale W.M., Pheloung P.C. (2006) Quantifying Uncertainty in Predictions of Invasiveness, Biol. Invasions 8, 277-286.

Carvalho F.P. (2006) Agriculture, pesticides, food security and food safety, Environ. Sci. Policy 9, 685-692.

CBD (Convention on Biological Diversity) (1992) Convention on Biological Diversity, available online at http://www.biodiv.org/doc/ legal/cbd-en.pdf.

Cembali T., Folwell R.J., Wandschneider P., Eastwell K.C., Howell W.E. (2003) Economic implications of a virus prevention program in deciduous tree fruits in the US, Crop Prot. 22, 1149-1156. 
Chriél M., Stryhn H., Dauphin G. (1999) Generalised linear mixed models analysis of risk factors for contamination of Danish broiler flocks with Salmonella typhimurium, Prev. Vet. Med. 40, 1-17.

Christiaans T., Eichner T., Pethig R. (2007) Optimal pest control in agriculture, J. Econ. Dynam. Control 31, 3965-3985.

Colautti R.I., Bailey S.A., van Overdijk C.D.A., Amundsen K., MacIsaac H.J. (2006) Characterised and projected costs of nonindigenous species in Canada, Biol. Invasions 8, 45-59.

Connelly N.A., O’Neill C.R. Jr., Knuth B.A., Brown T.L. (2007) Economic impacts of zebra mussels on drinking water treatment and electric power generation facilities, Environ. Manag. 40, 105112 .

Cook D. (2005) The 'Paradox of Thrips': identifying a critical level of investment in pest exclusion activities in Western Australia, Aust. Agribusiness Rev. 13, paper 11.

Cook D., Proctor W. (2007) Assessing the threat of exotic plant pests, Ecol. Econ. 63, 594-604.

Cook D.C. (2008) Benefit cost analysis of an import access request, Food Policy 33, 277-285.

Cook D.C., Thomas M.B., Cunningham S.A., Anderson D.L., De Barro P.J. (2007) Predicting the economic impact of an invasive species on an ecosystem service, Ecol. Appl. 17, 1832-1840.

Costello C., McAusland C. (2003). Protectionism, trade, and measures of damage from exotic species introductions, Am. J. Agr. Econ. 85, 964-975.

Costello C., Springborn M., McAusland C., Solow A. (2007) Unintended biological invasions: does risk vary by trading partner? J. Environ. Econ. Manage. 54, 262-276.

Council of Europe (2003) European strategy on invasive alien species, Strasbourg 5 September, 2003, T-PVS (2003), 7.

Cowan P.E. (1992) The eradication of introduced Australian brushtail possums, Trichosurus vulpecula, from Kapiti Island, a New Zealand nature reserve, Biol. Conserv. 61, 217-226.

Daily G.C., Ehrlich P.R. (1996) Impacts of development and global change on the epidemiological environment, Environ. Dev. Econ. $1,311-346$.

Dalmazzone S. (2000) Economic factors affecting vulnerability to biological invasions, in: Perrings C., Williamson M., Dalmazzone S. (Eds.), 2000. The economics of biological invasions, Edward Elgar, Cheltenham.

De Vos C.J., Saatkamp H.W., Huirne R.B.M. (2005) Cost-effectiveness of measures to prevent classical swine fever introduction into The Netherlands, Prev. Vet. Med. 70, 235-256.

Dehnen-Schmutz K., Perrings C., Williamson M. (2004) Controlling Rhododendron ponticum in the British Isles: an economic analysis, J. Environ. Manage. 70, 323-332.

Dehnen-Schmutz K., Touza J., Perrings C., Williamson M. (2007) A century of the ornamental plant trade and its impact on invasion success, Diversity and Distributions 13, 527-534.

Delfino D., Simmons P.J. (2000) Infectious diseases as invasives in human population, in: Perrings C., Williamson M., Dalmazzone S. (Eds.), 2000. The economics of biological invasions, Edward Elgar, Cheltenham.

Dixon B. (2007) A rotten end, The Lancet 7, 375.

Djunaidi H., Djunaidi A.C.M. (2007) The economic impacts of avian influenza on world poultry trade and the U.S. poultry industry: a spatial equilibrium analysis, J. Agric. Appl. Econ. 39, 313-323.

Eiswerth M.E., van Kooten G.C. (2002) Uncertainty, economics and the spread of an invasive plant species, Am. J. Agric. Econ. 84, 13171322.
Elbakidze L. (2003) The economics of agricultural bio-security: an interpretive literature review, Texan A\&M University Report.

Elbakidze L., McCarl B.A. (2005) Ex ante vs. ex post bioterrorism mitigation: better safe than sorry? Paper prepared for presentation at the American Agricultural Economics Association Annual Meeting, Providence, Rhode Island, 24-27 July 2005.

European Commission (2006) Evaluation of the Community animal health policy (CAHP) 1995-2004 and alternatives for the future, available at: http://ec.europa.eu/food/animal/diseases/strategy/ main_report_part1_en.pdf.

Evans E.A., Spreen T.H., Knapp J.L. (2002) Economic issues of invasive pests and diseases and food safety, International Agricultural Trade and Policy Center Monograph Series MGTC02-2, University of Florida.

FAO (2001) Economic impacts of transboundary plant pests and animal diseases, in: FAO, The State of Food and Agriculture 2001, FAO, Rome, Italy.

FAO (2003) Committee on Agriculture, Seventeenth session: Biosecurity in Food and Agriculture, Rome, 31 March-4 April 2003.

FAO/CTD (2006) Impact of animal disease outbreaks on livestock markets: an FAO analysis, available at: http://www.fao.org/es/ esc/common/ecg/157/en/Paper_Impact_of_Animal_Disease_ Outbreaks_on_Livestock_Markets_FAÖ.pdf.

Fasina F.O., Meseko A.C., Joannis T.M., Shittu A.I., Ularamu H.G., Egbuji N.A., Sulaiman L.K., Onyekonwu N.O. (2007) Control versus no control: options for avian influenza H5N1 in Nigeria, Zoonoses and Public Health 54, 173-176.

Fernandez L. (2008) NAFTA and member country strategies for maritime trade and marine invasive species, J. Environ. Manage. 89, 308321.

Finnoff D., Shogren J.F., Leung B., Lodge D. (2007) Take a risk: preferring prevention over control of biological invaders, Ecol. Econ. 62, 216-222.

Food Outlook (2006) Impact of animal disease outbreaks on livestock markets: an FAO analysis, No. 2, December 2006.

Gebhardt H. (1996) Ecological and economic consequences of introductions of exotic wildlife (birds and mammals) in Germany, Wildlife Biol. 2, 205-211.

Genovesi P. (2005) Eradications of invasive alien species in Europe: a review, Biol. Invasions 7, 127-133.

Goldbach S.G., Alban L. (2006) A cost-benefit analysis of Salmonellacontrol strategies in Danish pork production, Prev. Vet. Med. 77, $1-14$.

Gramig B.M., Wolf C.A. (2007) Estimating within-herd preventive spillovers in livestock disease management, Am. J. Agric. Econ. $89,1219-1225$.

Gren I.-M. (2008) Economics of alien invasive species management choices of targets and policies, Boreal Environ. Res. 13, 17-32.

Gutrich J.J., VanGelder E., Loope L. (2007) Potential economic impact of introduction and spread of the red imported fire ant, Solenopsis invicta, in Hawaii, Environ. Sci. Policy 10, 685-696.

Harris R. (2005) Invasive ant risk assessment: ranking of high-risk species, available at: http://www.landcareresearch.co.nz/research/ biocons/invertebrates/Ants/ant_pest_risk.asp.

Hastings A., Hall R.J., Taylor C.M. (2006) A simple approach to optimal control of invasive species, Theor. Popul. Biol. 70, 431-435.

Heal G., Kriström B. (2002) Uncertainty and climate change, Environ. Res. Econ. 22, 3-39.

Heath S.E. (2006) Challenges and options for animal and public health services in the next two decades, Office International des Épizootics (OIE) Scientific and Technical Review 25, 403-419. 
Heikkilä J., Pathogens, pests and weeds: risk classification principles and practices, unpublished manuscript.

Heikkilä J., Peltola J. (2007) Phytosanitary measures under uncertainty: a case study of Colorado potato beetle in Finland, in: Oude Lansink A.G.J.M. (Ed.), New approaches to the economics of plant health, Wageningen UR Frontis Series, Vol. 20, Springer.

Heikkilä J. Economics of invasive alien species: pre-emptive versus reactive control, Licentiate Thesis, MTT Discussion Papers 9/2006.

Hennessy D.A. (2007) Biosecurity and spread of an infectious animal disease, Am. J. Agric. Econ. 89, 1226-1231.

Higgins S.I., Turpie J.K., Constanza R., Cowling R.M., Le Maitre D.C., Marais C., Midgley G.F. (1997) An ecological economic simulation model of mountain fynbos ecosystems: dynamics, valuation and management, Ecol. Econ. 22, 155-169.

Hilje L., Stansly P.A. (2008) Living ground covers for management of Bemisia tabaci (Gennadius) (Homoptera: Aleyrodidae) and tomato yellow mottle virus (ToYMoV) in Costa Rica, Crop Prot. 27, 10-16.

Horan R.D., Lupi F. (2005) Tradeable risk permits to prevent future introductions of invasive alien species into the Great Lakes, Ecol. Econ. 52, 289-304.

Horan R.D., Perrings C., Lupi F., Bulte E.H. (2002) Biological pollution prevention strategies under ignorance: the case of invasive species, Am. J. Agric. Econ. 84, 1303-1310.

Houben E.H.P., Huirne R.B.M., Dijkhuizen A.A., Kristensen A.R. (1994) Optimal replacement of mastitic cows determined by a hierarchic Markov process, J. Dairy Sci. 77, 2975-2993.

Houe H. (2003) Economic impact of BVDV infection in dairies, Biologicals 31, 137-143.

Hundley K. (2007) Power plant: Is Arundo donax the answer to our power problems? St. Petersburg Times, 11 February 2007, available at: http://www.sptimes.com/2007/02/11/Business/Power_plant Is_Arun.shtml.

IMF (2006) The global economic and financial impact of an avian flu pandemic and the role of the IMF, Avian Flu Working Group.

James A.D., Rushton J. (2002) The economics of foot and mouth disease, Office International des Épizootics (OIE) Scientific and Technical Review 21, 637-644.

Jenkins P. (2001) Who should pay? Economic dimensions of preventing harmful invasions through international trade and travel, in: McNeely J.A. (Ed.), 2001. The great reshuffling: human dimensions of invasive alien species, IUCN.

Jensen H.H., Unnevehr L.J., Gómez M.I. (1998) Costs of improving food safety in the meat sector, J. Agric. Appl. Econ. 30, 83-94.

Jensen R. (2002) Economic policy for invasive species, Working Paper, available online at http://www.nd.edu/ rjensen1/workingpapers/ InvasiveSpecies.pdf.

Johansson R., Livingston M., Westra J., Guidry K. (2005) Preliminary estimates of U.S. economic and environmental effects of treating and adjusting to Asian soybean rust, Presentation at Northeasters Agricultural and Resource Economics Association's Economics of Invasive Species workshop, Annapolis, Maryland, 14-15 June 2005.

Jones K.R., Corona J.P. (2008) An ambient tax approach to invasive species, Ecol. Econ. 64, 534-541.

Keller R.P., Lodge D.M., Finnoff D.C. (2007) Risk assessment for invasive species produces net bioeconomic benefits, Proc. Nat. Acad. Sci. 104, 203-207.

Kim C.S., Lubowski R., Lewandrowski J. (2005) Prevention or control? Optimal government policies for invasive species management, A paper presented at the Northeastern Agricultural and Resource Economics Association's (NAREA) workshop on Invasive Species, Annapolis, Maryland, 14-15 June 2005, available online at: http://
www.arec.umd.edu/llynch/personal\%20files/NAREA-IS-Work. htm.

Klinkenberg D., Nielen M., Mourits M.C.M., de Jong M.C.M. (2005) The effectiveness of classical swine fever surveillance programmes in The Netherlands, Prev. Vet. Med. 67, 19-37.

Knowler D. (2005) Reassessing the costs of biological invasion: Mnemiopsis leidyi in the Black sea, Ecol. Econ. 52, 187-199.

Knowler D., Barbier E.B. (2000) The economics of an invading species: a theoretical model and case study application, in: Perrings C., Williamson M., Dalmazzone S. (Eds.), 2000. The economics of biological invasions, Edward Elgar, Cheltenham.

Knowler D., Barbier E. (2005) Importing exotic plants and the risk of invasion: are market-based instruments adequate? Ecol. Econ. 52, 341-354.

Kobayashi M., Carpenter T.E., Dickey B.F., Howitt R.E. (2007) A dynamic, optimal disease control model for foot-and-mouth disease: I. Model description, Prev. Vet. Med. 79, 257-273.

Leung B., Lodge D.M., Finnoff D., Shogren J.F., Lewis M.A., Lamberti G. (2002) An ounce of prevention or a pound of cure: bioeconomic risk analysis of invasive species, Proc. R. Soc. Lond. B. 269, 2407 2413.

Lichtenberg E., Penn T.M. (2003) Prevention versus treatment under precautionary regulation: a case study of groundwater contamination under uncertainty, Am. J. Agric. Econ. 85, 44-58.

MacLeod A., Baker R.H.A., Cannon R.J.C. (2005) Costs and benefits of European Community (EC) measures against invasive alien species - current and future impacts of Diabrotica virgifera virgifera in England \& Wales, A paper prepared for symposium on Introduction and Spread of Invasive Species, 9-11 June 2005, Berlin, Germany.

MacLeod A., Evans H.F., Baker R.H.A. (2002) An analysis of pest risk from an Asian longhorn beetle (Anoplophora glabripennis) to hardwood trees in the European community, Crop Prot. 21, 635-645.

Mahul O., Gohin A. (1999) Irreversible decision making in contagious animal disease control under uncertainty: an illustration using FMD in Brittany, Eur. Rev. Agric. Econ. 26, 39-58.

Maijala R., Ranta J., Seuna E., Peltola J. (2005) The efficiency of the Finnish salmonella control programme, Food Control, 16, 669-675.

Mangen M.-J.J., Burrell A.M. (2003) Who gains, who loses? Welfare effects of classical swine fever epidemics in the Netherlands, Eur. Rev. Agric. Econ. 30, 125-154.

Mangen M.-J.J., Jalvingh A.W., Nielen M., Mourits M.C.M., Klinkenberg D., Dijkhuizen A.A. (2001) Spatial and stochastic simulation to compare two emergency-vaccination strategies with a marker vaccine in the $1997 / 8$ Dutch classical swine fever epidemic, Prev. Vet. Med. 48, 177-200.

Mangen M.-J.J., Nielen M., Burrell A.M. (2002) Simulated effect of pigpopulation density on epidemic size and choice of control strategy for classical swine fever epidemics in The Netherlands, Prev. Vet. Med. 56, 141-163.

Margolis M., Shogren J.F., Fischer C. (2005) How trade policies affect invasive species control, Ecol. Econ. 52, 305-313.

Martin P. (2003) Killing us softly - Australia's green stalkers: a call to action on invasive plants, and a way forward, CRC for Australian Weed Management.

McAusland C., Costello C. (2004) Avoiding invasives: trade-related policies for controlling unintentional exotic species introductions, J. Environ. Econ. Manage. 48, 954-977.

McInerney J., Kooij D. (1997) Economic analysis of alternative AD control programmes, Vet. Microbiol. 55, 113-121.

McInerney J.P., Howe K.S., Schepers J.A. (1992) A framework for the economic analysis of disease in farm livestock, Prev. Vet. Med. 13, $137-154$. 
McKee G.J., Goodhue R.E., Zalom F.G., Carter C.A., Chalfant J.A (2008) Population dynamics and the economics of invasive species management: the greenhouse whitefly in California-grown strawberries, J. Environ. Manage. (in press).

McKenzie J., Simpson H., Langstaff I. (2007) Development of methodology to prioritise wildlife pathogens for surveillance, Prev. Vet. Med. 81, 194-210.

Mehta S.V., Haight R.G., Homans F.R., Polasky S., Venette R.C. (2007) Optimal detection and control strategies for invasive species management, Ecol. Econ. 61, 237-245.

Moffitt L.J., Osteen G.D. (2006) Prioritizing invasive species threats under uncertainty, Agric. Res. Econ. Rev. 35, 41-51.

Moffitt L.J., Stranlund J.K., Field B.C., Osteen C.D. (2008) Robust inspection for invasive species with a limited budget, J. Environ. Manage. 89, 293-299.

Mort M., Convery I., Baxter J., Bailey C. (2005) Psychosocial effects of the 2001 UK foot and mouth disease epidemic in a rural population: qualitative diary based study, BMJ, DOI: 10.1136/bmj.38603.375856.68 (published 7 October 2005)

Mukhebi A.W., Chamboko T., O'Callaghan C.J., Peter T.F., Kruska R.L., Medley G.F., Mahan S.M., Perry B.D. (1999) An assessment of the economic impact of heartwater (Cowdria ruminantium infection) and its control in Zimbabwe, Prev. Vet. Med. 39, 173-189.

Mumford J.D. (2002) Economic issues related to quarantine in international trade, Eur. Rev. Agric. Econ. 29, 329-348.

Mumford J.D., Temple M.L., Quinlan M.M., Gladders P., Blood-Smyth J.A., Mourato S.M., Makuch Z., Crabb R.J. (2000) Economic policy evaluation of MAFF's Plant Health Programme. Report to Ministry of Agriculture Fisheries and Food, London, United Kingdom, available at: http://statistics.defra.gov.uk/esg/evaluation/ planth/.

Niemi J.K., Pietola K. (2004) Pigmeat producer incentives and moral hazard under contagious animal disease restrictions, Paper presented at 86th EAAE Seminar Farm income stabilisation: what role should public policy play? Anacapri.

Niemi J.K., Lehtonen H., Pietola K., Lyytikäinen T., Raulo S. (2008) Simulated financial losses of classical swine fever epidemics in the Finnish pig production sector, Prev. Vet. Med. 84, 194-212.

Olson L.J. (2006) The economics of terrestrial invasive species: a review of the literature, Am. J. Agric. Econ. 35, 178-194.

Olson L.J., Roy S. (2002) The economics of controlling a stochastic biological invasion, Am. J. Agric. Econ. 84, 1311-1316.

Otsuki T., Wilson J.S., Sewadeh M. (2001) Saving two in a billion: a case study to quantify the trade effect of European food safety standards on African exports, Food Policy 26, 495-514.

Oude Lansink A.G.J.M. (2007) New approaches to the economics of plant health, Wageningen UR Frontis Series, Vol. 20, Springer.

Paarlberg P., Lee J. (1998) Import restrictions in the presence of a health risk: an illustration using FMD, Am. J. Agric. Econ. 80, 175-183

Paarlberg P.L., Hillberg Seitzinger A., Lee J.G. (2007) Economic impacts of regionalization of a highly pathogenic avian influenza outbreak in the United States, J. Agric. Appl. Econ. 39, 325-333.

Parker C., Caton B.P., Fowler L. (2007) Ranking nonindigenous weed species by their potential to invade the United States, Weed Sci. 55, 386-397.

Peeler E.J., Murray A.G., Thebault A., Brun E., Giovaninni A., Thrush M.A. (2007) The application of risk analysis in aquatic animal health management, Prev. Vet. Med. 81, 3-20.

Perrault A., Carroll Muffett W. (2001) Encouraging prevention, developing capacity and providing accountability: a strategy for addressing international invasive alien species issues, Center for International Environmental Law Discussion Paper, Washington DC.
Perrings C. (2000) The economics of biological invasions, in: Preston G., Brown A.G., van Wyk E. (Eds.), 2000. Best Management Practices for Preventing and Controlling Invasive Alien Species, Symposium Proceedings, Cape Town, South Africa: Working for Water Programme.

Perrings C. (2005) Mitigation and adaptation strategies for the control of biological invasions, Ecol. Econ. 52, 315-325.

Perrings C., Williamson M., Dalmazzone S. (2000) The economics of biological invasions, Edward Elgar, Cheltenham.

Perry B.D., Randolph T.F. (1999) Improving the assessment of the economic impacts of parasitic diseases and of their control in production animals, Vet. Parasitol. 84, 145-168.

Persson U., Jendteg S. (1992) The economic impact of poultry-borne salmonellosis: how much should be spent on prophylaxis? Int. J. Food Microbiol. 15, 207-213.

Pifafi B.A., Rousmasset J.A. (2007) Some resource economics of invasive species, A paper presented at the 15th Annual Conference of the European Association of Environmental and Resource Economists (EAERE), 27-30 June 2007, Thessaloniki, Greece.

Pimentel D., Lach L., Zuniga R., Morrison D. (1999) Environmental and economic costs associated with non-indigenous species in the United States, http://www.news.cornell.edu/releases/Jan99/ species_costs.html.

Pimentel D., McNair S., Janecka J., Wightman J., Simmonds C., O'Connell C., Wong E., Russel L., Zern J., Aquino T., Tsomondo T. (2001) Economic and environmental threats of alien plant, animal, and microbe invasions, Agric. Ecosyst. Environ. 84, 1-20.

Pimentel D., Zuniga R., Morrison D. (2005) Update on the environmental and economic costs associated with alien-invasive species in the United States, Ecol. Econ. 52, 273-288.

Powell M., Scott A., Ebel E. (2008) Analyzing BSE surveillance in low prevalence countries, Prev. Vet. Med. 83, 337-346.

Prattley D.J., Morris R.S., Stevenson M.A., Thornton R. (2007) Application of portfolio theory to risk-based allocation of surveillance resources in animal populations, Prev. Vet. Med. 81, 56-69.

Pysek P., Richardson D.M., Pergl J., Jarosik V., Sixtová Z., Weber E. (2008) Geographical and taxonomic biases in invasion ecology, Trends Ecol. Evol. 23, 237-244.

Ranjan R., Marshall E., Shortle J. (2008) Optimal renewable resource management in the presence of endogenous risk of invasion, J. Environ. Manage. 89, 273-283.

Reinhardt F., Herle M., Bastiansen F., Streit B. (2003) Economic impact of the spread of alien species in Germany, German Federal Environmental Agency report number 80/2003.

Renn O. (2006) Risk governance: towards an integrative approach, White Paper No. 1, International Risk Governance Council, Geneva.

Rich K.M., Winter-Nelson A. (2007) An integrated epidemiologicaleconomic analysis of foot-and-mouth disease: applications to the Southern Cone of South America, Am. J. Agric. Econ. 89, 682697.

Roberts T. (1989) Human illness costs of foodborne bacteria, Am. J. Agric. Econ. 71, 468-474.

Rosengren H., Heikkilä J. (2009) Risk-based classification of animal diseases: the case of poultry, A poster presented at the 12th International Symposium on Veterinary Epidemiology and Economics (ISVEE XII), 10-14 August 2009, Durban, South Africa.

Ross J.V., Pollett P.K. (2007) On costs and decisions in population management, Ecol. Model. 201, 60-66.

Rossides S.C. (2002) A farming perspective on the 2001 foot and mouth disease epidemic in the United Kingdom, Office International des Épizootics (OIE) Scientific and Technical Review 21, 831-838. 
Rushton J., Upton M. (2006) Investment in preventing and preparing for biological emergencies and disasters: Social and economic costs of disasters versus costs of surveillance and response preparedness, Office International des Épizootics (OIE) Scientific and Technical Review 25, 378-388.

Russell J., Choquenot D., Clout M., Beggs J. (2006) Developing a framework for prioritising pest management policy, Report prepared for the Auckland Regional Council, Centre for Biodiversity and Biosecurity, Auckland.

Saatkamp H.W., Berentsen P.B.M., Horst H.S. (2000) Economic aspects of the control of classical swine fever outbreaks in the European Union, Vet. Microbiol. 73, 221-237.

Saatkamp H.W., Dijkhuizen A.A., Geers R., Huirne R.B.M., Noordhuizen J.P.T.M., Goedseels V. (1997) Economic evaluation of national identification and recording systems for pigs in Belgium, Prev. Vet. Med. 30, 121-135.

Schmitz D.C., Simberloff D. (1997) Biological invasions: a growing threat, Issues in Science and Technology 13, 33-40.

Schoenbaum M.A., Disney W.T. (2003) Modeling alternative mitigation strategies for a hypothetical outbreak of foot-and-mouth disease in the United States, Prev. Vet. Med. 58, 25-52.

Schrader G., Unger J.-G. (2003) Plant quarantine as a measure against invasive alien species: the framework of the International Plant Protection Convention and the plant health regulations in the European Union, Biol. Invasions 5, 357-364.

Sharov A.A. (2004) Bioeconomics of managing the spread of exotic pest species with barrier zones, Risk Analysis 24, 879-892.

Sharov A.A., Liebhold A.M. (1998) Bioeconomics of managing the spread of exotic pest species with barrier zones, Ecol. Appl. 8, 833845 .

Shine C., Williams N., Gündling L. (2000) A guide to designing legal and institutional frameworks on alien invasive species, Environmental Policy and Law Paper No. 40, Environmental Law Centre, The World Conservation Union.

Shogren J.F. (2000) Risk reduction strategies against the 'explosive invader', in: Perrings C., Williamson M., Dalmazzone S. (Eds.), 2000. The economics of biological invasions, Edward Elgar, Cheltenham, $249 \mathrm{p}$.

Shortle J.S. (2007) Economic incentives for managing infectious animal disease: discussion, Am. J. Agric. Econ. 89, 1239-1240.

Siekkinen K.-M., Heikkilä J., Tammiranta N., Rosengren H. (2008) The costs of biosecurity at the farm level: the case of Finnish broiler, A poster presented at the 12th Congress of the European Association of Agricultural Economists (EAAE), 26-29 August 2008, Gent, Belgium.

Simberloff D. (2003) How much information on population biology is needed to manage introduced species, Conserv. Biol. 17, 83-92.

Smith C.S., Lonsdane W.M., Fortune J. (1999) When to ignore advice: invasion predictions and decision theory, Biol. Invasions, 1, 89-96.

Sugiura K., Ito K., Yokoyama R., Kumagai S., Onodera T. (2003) A model to assess the risk of the introduction into Japan of the bovine spongiform encephalopathy agent through imported animals, meat and meat-and-bone meal, Office International des Épizootics (OIE), Scientific and Technical Review 22, 777-794.
Surkov I.V., Oude Lansink A.G.J.M., van Kooten O., van der Werf W. (2008) A model of optimal import phytosanitary inspection under capacity constraint, Agric. Econ. 38, 363-373.

Sutmoller P., Casas Olascoaga R. (2003) The risks posed by the importation of animals vaccinated against foot and mouth disease and products derived from vaccinated animals: a review, Office International des Épizootics (OIE) Scientific and Technical Review 22, 823-835.

Taylor C.M., Hastings A. (2004) Finding optimal control strategies for invasive species: a density-structured model for Spartina alterniflora, J. Appl. Ecol. 41, 1049-1057.

Tu A.T., Beghin J., Gozlan E. (2008) Tariff escalation and invasive species damages, Ecol. Econ. 67, 619-629.

U.S. Congress, Office of Technology Assessment (1993) Harmful nonindigenous species in the United States, OTA-F-565, Washington DC, available online at http://www.wws.princeton.edu/cgi-bin/ byteserv.prl/ ota/disk1/1993/9325/9325.pdf.

Valeeva N.I., Huirne R.B.M., Meuwissen M.P.M., Oude Lansink A.G.J.M. (2007) Modeling farm-level strategies for improving food safety in the dairy chain, Agric. Syst. 94, 528-540.

Valeeva N.I., Meuwissen M., Oude Lansink A., Huirne R. (2006) Cost implications of improving food safety in the Dutch dairy chain, Eur. Rev. Agric. Econ. 33, 511-541.

van der Gaag M.A., Saatkamp H.W., Backus G.B.C., van Beek P., Huirne R.B.M. (2004) Cost-effectiveness of controlling Salmonella in the pork chain, Food Control 15, 173-180.

Virtue J. (2007) Weed Risk Management in South Australia. Presentation at International Weed Risk Assessment Workshop (IWRAW) 2007, Perth (WA), Australia, 14-15 September 2007.

Waage J.K., Mumford J.D. (2008) Agricultural biosecurity, Philos. Trans. R. Soc. Lond. B 363, 863-876.

Waage J.K., Fraser R.W., Mumford J.D., Cook D.C., Wilby A. (2005) A new agenda for biosecurity, Faculty of Life Sciences, Imperial College London, London.

Weber E., Gut D. (2004) Assessing the risk of potentially invasive plant species in central Europe, J. Nature Conserv. 12, 171-179.

Weigle S.M., Smith L.D., Carlton J.T., Pederson J. (2005) Assessing the risk of introducing exotic species via the live marine species trade, Conserv. Biol. 19, 213-223.

WHO (2007) Food safety and foodborne illness, Fact sheet Number 237, Reviewed March 2007.

Wolfe N.D., Panosian Dunavan C., Diamond J. (2007) Origins of major human infectious diseases, Nature 447, 279-283.

Wooldridge M., Hartnett E., Cox A., Seaman M. (2006) Quantitative risk assessment case study: smuggled meats as disease vectors, Office International des Épizootics (OIE) Scientific and Technical Review $25,105-117$.

Work T.T., McGullough D.G., Cavey J.F., Komsa R. (2005) Arrival rate of nonindigenous insect species into the United States through foreign trade, Biol. Invasions 7, 323-332.

Xu H., Ding H., Li M., Qiang S., Guo J., Han Z., Huang Z., Sun H., He S., Wu H., Wan F. (2006) The distribution and economic losses of alien species invasion to China, Biol. Invasions 8, 1495-1500.

Zavaleta E. (2000) The economic value of controlling an invasive shrub, Ambio 29, 462-467. 